University of Nebraska - Lincoln

DigitalCommons@University of Nebraska - Lincoln

USDA National Wildlife Research Center - Staff

Publications

U.S. Department of Agriculture: Animal and Plant Health Inspection Service

February 2004

\title{
Biology and Culture of Channel Catfish
}

James F. Glahn

D. Tommy King

USDA/APHIS/WS National Wildlife Research Center, tommy.king@aphis.usda.gov

Follow this and additional works at: https://digitalcommons.unl.edu/icwdm_usdanwrc

Part of the Environmental Sciences Commons

Glahn, James F. and King, D. Tommy, "Biology and Culture of Channel Catfish" (2004). USDA National Wildlife Research Center - Staff Publications. 495.

https://digitalcommons.unl.edu/icwdm_usdanwrc/495

This Article is brought to you for free and open access by the U.S. Department of Agriculture: Animal and Plant Health Inspection Service at DigitalCommons@University of Nebraska - Lincoln. It has been accepted for inclusion in USDA National Wildlife Research Center - Staff Publications by an authorized administrator of DigitalCommons@University of Nebraska - Lincoln. 


\section{BIOLOGY AND CULTURE OF CHANNEL CATFISH}

\section{Edited by \\ CRAIG S. TUCKER \\ JOHN A. HARGREAVES}

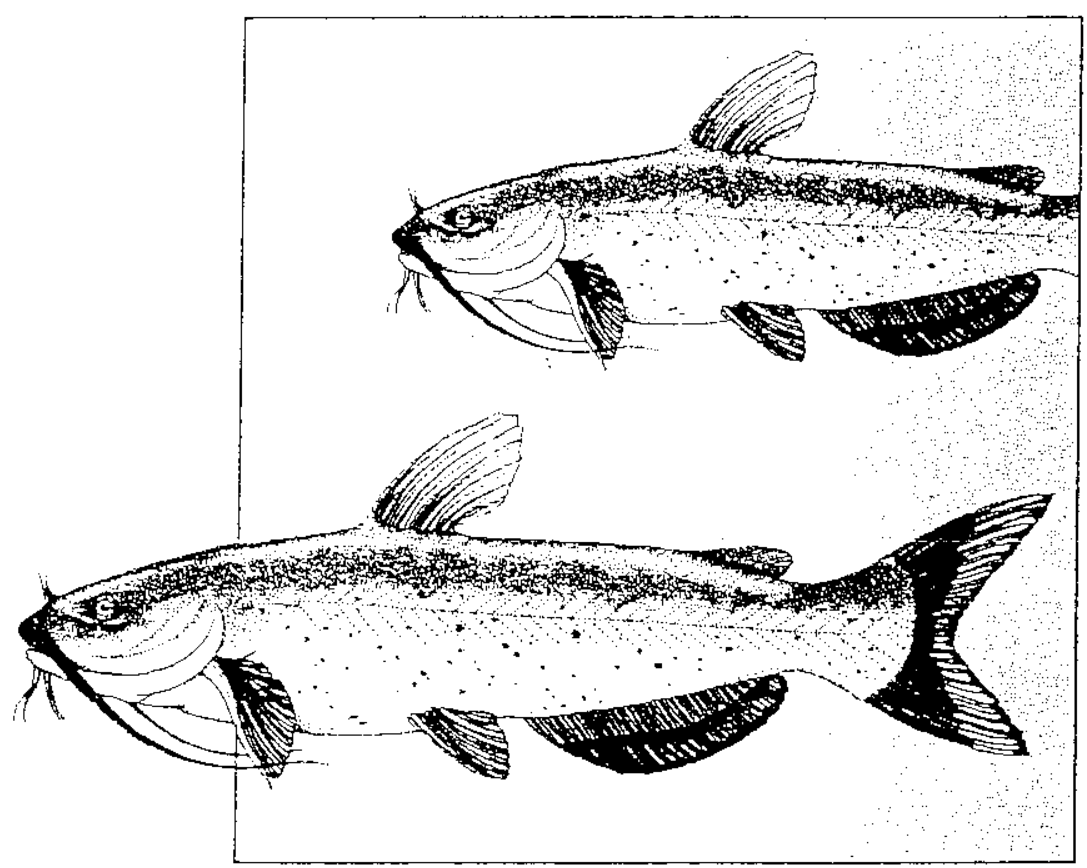

DEVELOPMENTS IN AQUACULTURE AND FISHERIES SCIENCE - 34 


\section{Bird Depredation}

\section{James F. Glahn and D. Tommy King}

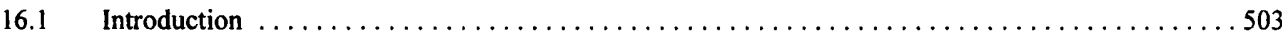

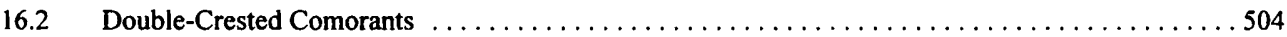

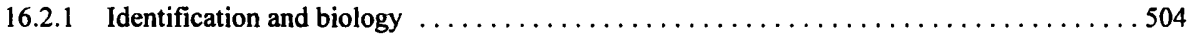

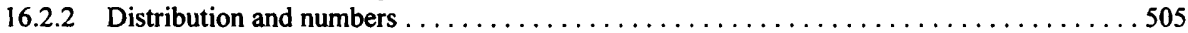

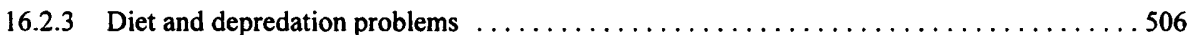

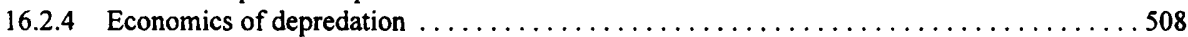

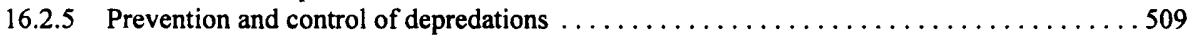

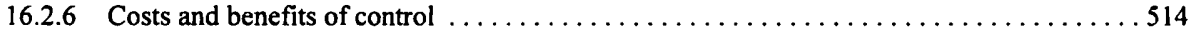

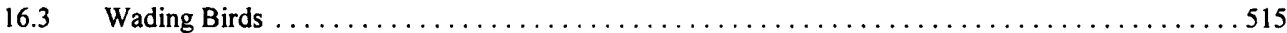

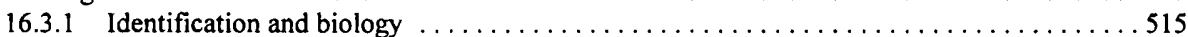

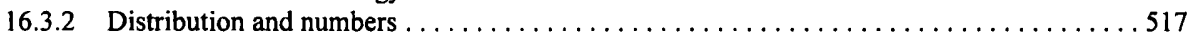

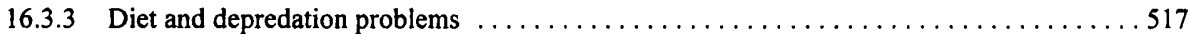

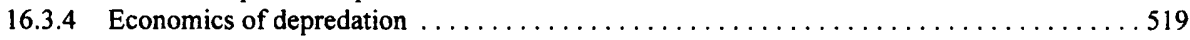

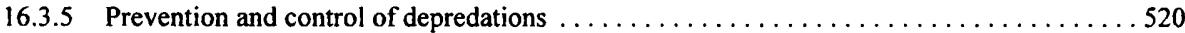

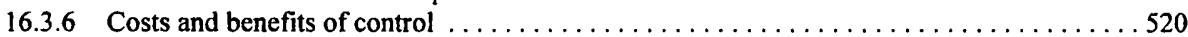

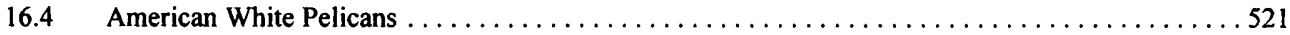

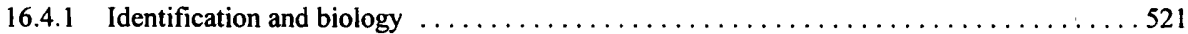

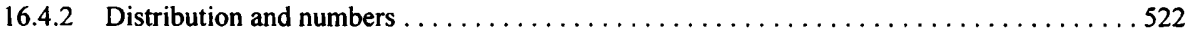

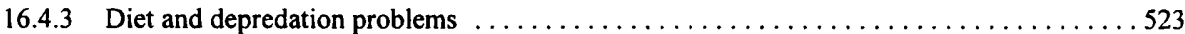

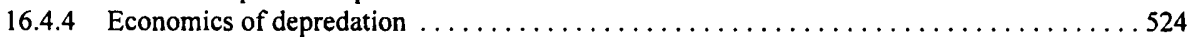

16.4.5 Prevention and control of depredations $\ldots \ldots \ldots \ldots \ldots \ldots \ldots \ldots \ldots \ldots \ldots \ldots \ldots \ldots$

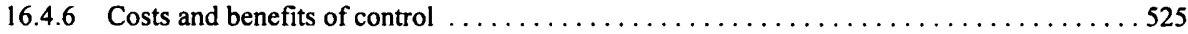

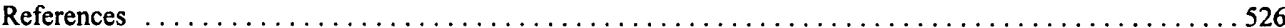

\subsection{INTRODUCTION}

A survey of catfish producers by the United States Department of Agriculture, Centers for Epidemiology and Animal Health (CEAH) in 1996 indicated that the two primary sources of catfish losses in commercial operations were disease (45\%) and wildlife (37\%) (CEAH 1997a). A variety of avian and mammalian predators are attracted to aquaculture facilities in the United States (Parkhurst et al. 1992) because ponds and open raceways provide a constant and readily accessible food supply for these animals. However, the mere presence of these predators arcund aquaculture facilities does not necessarily mean that significant depredation problems are occurring. At catfish farms, three species or species groups of birds are primarily cited by catfish producers as causing most depredation problems (Wywialowski 1999). These include doublecrested cormorants, wading birds (herons and egrets), and American white pelicans, in order of importance to catfish producers (Wywialowski 1999). Although all of these species consume catfish, their biology, distribution, and dietary preferences dictate the extent of depredation problems they cause and the approaches needed to alleviate their depredations. With the exception of total bird exclusion from ponds, there are no simple solutions for resolving all bird 


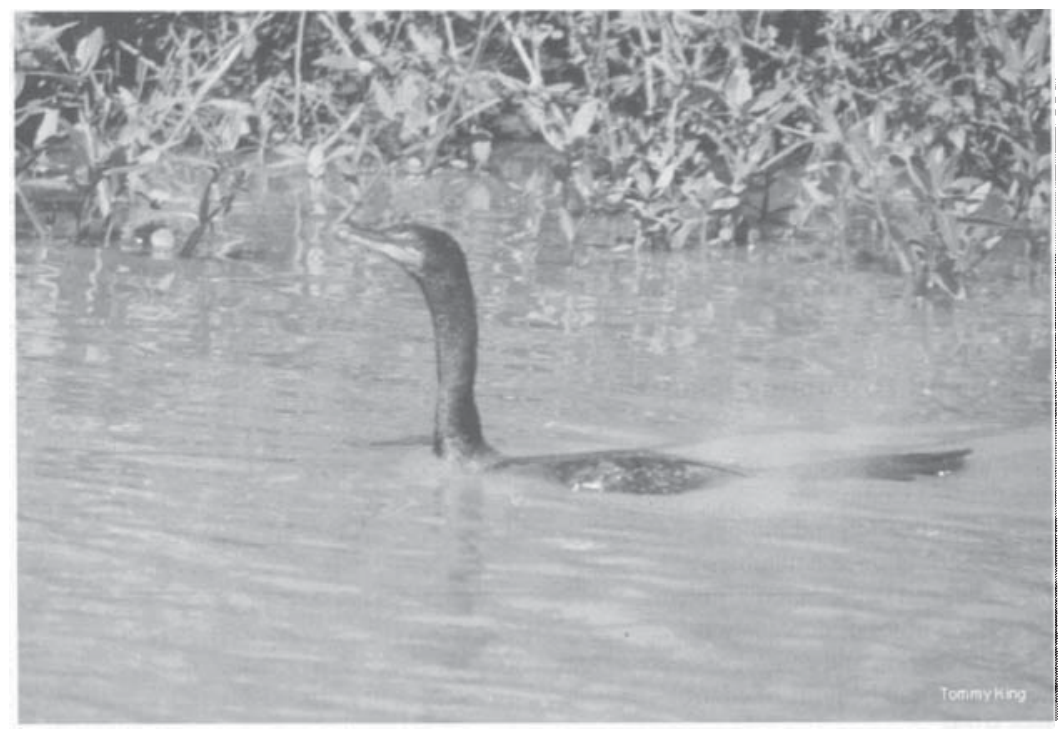

FIGURE 16.1. Double-crested cormorant.

depredation problems in catfish aquaculture. Thus, in most cases, an integrated management approach to alleviating bird depredations must be considered.

\subsection{DOUBLE-CRESTED CORMORANTS}

The double-crested cormorant Phalacrocorax auritus (Fig. 16.1) is part of a group of cosmopolitan seabirds that are highly adapted to foraging on fish in open waters. Of six species of cormorants occurring in North America, it is the only one to occur in large numbers in the interior and on the coasts (Hatch and Weseloh 1999). Because of its adaptation to fishing, the doublecrested cormorant has long been perceived to conflict with sport and commercial fishing interests (Meister and Gramlich 1967), but its conflict with aquaculture has more recently coincided with the development of extensive areas of large ponds associated with catfish farming in the United States (Glahn and Stickley 1995).

\subsubsection{Identification and biology}

The double-crested cormorant is a mostly black, goose-like bird with a hooked bill (Stickley 1990). The double-crested cormorant is about $80 \mathrm{~cm}$ (ca. 30 inches) in length and weighs about $2.3 \mathrm{~kg}$ ( 5 pounds). Similar looking birds include the anhinga Anhinga anhinga and the neotropic cormorant Phalacrocorax brasilianus (Johnsgard 1993). Although the anhinga occurs throughout the Gulf states in the summer, it has a longer, pointed bill and silvery white streaks on the wings and back. The smaller neotropic cormorant occurs only along the Gulf coast and has white 
markings above and below the eye. Like geese, double-crested cormorants (hereafter called cormorants) fly in ' $\mathrm{V}$ ' formations and are extremely gregarious migratory birds, occuring in flocks from several birds to several thousand birds. On catfish ponds and other wetlands, they swim low in the water, often with little more than their heads and sinuous necks showing (Hatch and Weseloh 1999). From the water's surface, they repeatedly dive and pursue prey underwater using. powerful strokes from their webbed feet. Cormorants grasp fish underwater with their hooked bill and typically surface with the fish to swallow it head first (Hatch and Weseloh 1999). Although they prefer to forage in shallow water, cormorants have been known to dive $22 \mathrm{~m}$ ( 72 feet) to obtain prey (Lewis 1929).

\subsubsection{Distribution and numbers}

Double-crested cormorants are widely distributed throughout North America (Hatch and Weseloh 1999). Most of the double-crested cormorants that affect southern catfish producers breed east of the Rocky Mountains, primarily from the Great Lakes through central Canada (Dolbeer 1991). However, small breeding colonies have recently been documented in Mississippi (Reinhold et al. 1998) and Arkansas (Thurmond Booth, USDA-Wildlife Services, Little Rock, Arkansas, personal communication). Up to $70 \%$ of the breeding cormorants banded at nesting colonies from Saskatchewan through the Great Lakes prior to 1988 were recovered in the Lower Mississippi River Valley and there was no apparent "focal point" of breeding birds that conflict with southern aquaculture (Dolbeer 1991).

Although cormorant breeding populations were suppressed prior to 1970 , populations have increased by $1,000 \%$ since that time and are now estimated between 1 and 2 million birds (Hatch 1995; Tyson et al. 1999). Factors contributing to this resurgence include the reduction of persistent pesticides in the environment, increased protection under the 1972 Migratory Bird Treaty Act, and increased food availability of alewife Alosa psuedoharengus on their northern breeding grounds and catfish on their southern wintering grounds (Glahn et al. 2000a).

Dramatic increases in the number of cormorants recorded on their wintering grounds in the southern United States has accompanied the resurgence in breeding populations and the growth of the catfish industry during the 1980s (Glahn and Stickley 1995; Jackson and Jackson 1995). In the catfish production region of northwest Mississippi, cormorant numbers recorded from roost counts have more than doubled in recent years from approximately 30,000 birds in 1990 to over 67,000 in 1998 (Glahn et al. 2000b). Cormorant numbers have remained approximately at 1998 levels through 2003 (Greg Ellis, USDA-Wildlife Services, Stoneville, Mississippi, personal communication). Less is known about wintering cormorants in other catfish production areas, but recent counts of roosting birds suggest populations of approximately 10,000 birds inhabit the rapidly expanding aquaculture region of east Mississippi and west Alabama (Glahn et al. 2000a). In the catfish production region of Arkansas, censuses in February 2000 revealed 50,000 cormorants roosting in several different sites (Glahn et al. 2000a). Despite the value of these census data as indices to potential conflicts, little is known about overall cormorant populations that might utilize catfish production areas throughout the winter months. However, cormorant banding data suggest that approximately 120,000 birds moved through the lower Mississippi Valley in 1989 (Dolbeer 1990). Considering the increased breeding populations since that time, this number may have more than doubled (Glahn et al. 2000a).

Historically, cormorants arrived on their wintering grounds in November and departed by mid-April (Aderman and Hill 1995). Appreciable numbers now arrive in September and do not 
depart until late April or early May (Reinhold and Sloan 1999), thus extending the period of depredations. On their wintering grounds, cormorants congregate at a number of night roost sites, typically in cypress-swamp habitat, that are situated in close proximity to catfish production or other foraging areas (Aderman and Hill 1995; Glahn et al. 1996). From a dynamic number of active night roost sites, cormorants travel a mean distance of only $16 \mathrm{~km}$ to forage at nearby catfish ponds (King et al. 1995). Thus, depredations are likely highly concentrated on ponds in close proximity to active roost sites, but shifts in roosting activity (King 1996) may cause depredations to be a widespread problem.

\subsubsection{Diet and depredation problems}

Cormorant depredations on catfish are a widespread problem. In a 1996 survey of catfish producers, depredations by cormorants were cited by $77 \%$ of Mississippi producers, $66 \%$ of Arkansas producers, and 50\% of Alabama producers (Wywialowski 1999). The main problems reported were cormorants feeding on catfish, injuring catfish, and disturbing feeding patterns of catfish (Wywialowski 1999). Although impacts from injuring and disturbing catfish have not been documented, observational studies have provided concrete evidence of cormorants consuming large numbers of live catfish. In Florida, the smaller taxonomic race of cormorants that reside there were observed consuming catfish fingerlings at a rate of 19 fingerlings/bird per day, or approximately $304 \mathrm{~g}$ (0.67 pounds) of catfish/bird per day (Schramm et al. 1984). With the larger race of cormorant in Mississippi, Stickley et al. (1992) found that cormorants consumed an average of 5 catfish per cormorant-hour of foraging. Based on this rate of catfish consumption and an average population of 30 cormorants utilizing catfish ponds, Stickley et al. (1992) estimated that half of a fingerling pond population stocked with 51,000 fish/ha (ca. 21,000 fish/acre) would be depleted in 167 days.

Food habits studies have also documented the prevalence of catfish in the diet of cormorants wintering in the catfish production region of northwest Mississippi (Glahn et al. 1995). Of 461 cormorants collected from night roosts during the winters of 1989-90 and 1990-91, catfish comprised about half of the cormorant diet by weight. The diet of 202 birds collected from catfish farms showed only a slightly higher percentage of catfish. Gizzard shad Dorosoma cepedianum comprised most of the remaining diet in each collection. Analysis of data from roost collections suggested that catfish were most often consumed during the spring from cormorants roosting in close proximity to concentrations of catfish farms. In contrast, very few catfish were consumed during the early winter or by cormorants roosting close to expansive natural wetlands along the Mississippi River. Catfish consumed by cormorants averaged approximately $16 \mathrm{~cm}$ (6.3 inches), and almost $70 \%$ of all catfish consumed were stocker-size catfish ranging from 10 to $20 \mathrm{~cm}$ (ca. 4 to 8 inches) (Glahn et al. 1995).

Based on cormorant populations, their diet, and physiological parameters, a bioenergetics model was constructed to estimate the overall removal of catfish by cormorants roosting in the catfish production region of northwest Mississippi during the winters of 1989-90 and 1990-91 (Glahn and Brugger 1995). This model projected that cormorants consumed from 18 to 20 million catfish fingerlings per winter, or approximately $4 \%$ of the estimated available fingerlings in the region. Because of increasing populations and shifts in the diet towards more catfish in the spring, more than half of the catfish losses occurred during February and March of each year. Using updated population estimates, recent projections from this model suggest that catfish losses during the winters of 1997-98 and 1998-99 ranged from 47 to 48 million catfish fingerlings 
TABLE 16.1. Catfish production losses from cormorant predation simulating 500 cormorants-days/ha (one cormorant/0.02-ha pond-half for 10 days). Research ponds ( 0.04 ha) were stocked with 12,355 catfish/ha in a single-batch cropping system and $5 \mathrm{~kg}$ of $8 \mathrm{to} 10 \mathrm{~cm}$ golden shiners to serve as a "buffer prey" (Glahn and Dorr 2002). Two replications (A and B) were conducted during the growing seasons of 1999 and 2000 , respectively, with three ponds in each trial; however, one pond in each trial had a catastrophic loss and data were not used in the analysis.

\begin{tabular}{|c|c|c|c|c|c|}
\hline \multirow[b]{2}{*}{ Trial } & \multirow[b]{2}{*}{ Pond } & \multirow[b]{2}{*}{ Fish stocked } & \multicolumn{3}{|c|}{ Catfish losses from cormorant predation } \\
\hline & & & Number ${ }^{\mathrm{a}}$ & $\%$ by number & $\%$ of biomass \\
\hline \multirow[t]{3}{*}{$\overline{\mathrm{A}^{\mathrm{b}}}$} & 1 & 250 & 62 & 25.6 & 18.7 \\
\hline & 2 & 250 & 79 & 33.3 & 20.6 \\
\hline & mean & 250 & 70.5 & 29.5 & 19.7 \\
\hline \multirow[t]{3}{*}{$B^{c}$} & 1 & 250 & 81 & 42.4 & 55.0 \\
\hline & 2 & 250 & 101 & 69.1 & 67.5 \\
\hline & mean & 250 & 91 & 56.0 & 61.0 \\
\hline
\end{tabular}

a The number of fish lost was calculated as the difference in number of fish inventoried from split pond halves with and without cormorant predation.

${ }^{b}$ During this trial, ponds did not experience disease outbreaks and cormorants were observed to feed on "buffer prey" in equal proportion to catfish.

'During this trial, ponds suffered moderate disease problems and cormorants were rarely observed to feed on "buffer prey."

annually, with greatest losses occurring in March (Glahn et al. 2000b). Based on physiological parameters, cormorant fish consumption was estimated to be $500 \mathrm{~g} / \mathrm{bird}$ per day $(1.1$ pounds/bird per day). This is consistent with recent studies in which two groups of captive cormorants consumed from 516 to $608 \mathrm{~g}$ (1.14 to 1.34 pounds) of catfish/bird per day from research ponds, or the equivalent of ten 18-cm (7-inch) fingerlings/bird per day (Glahn and Dorr 2002).

To examine the impact of cormorant depredations on production losses at harvest, Glahn and Dorr (2002) conducted a controlled foraging experiment with captive cormorants on research ponds. Each of six, 0.04-ha (0.1-acre) ponds were split in half and each pond-half stocked with $15-$ to $18-\mathrm{cm}$ (6- to 7 -inch) catfish fingerlings at a rate of $12,355 \mathrm{fish} / \mathrm{ha}(5,000 \mathrm{fish} / \mathrm{acre})$ using a single-batch cropping system. In addition, ponds were stocked with $5 \mathrm{~kg}$ ( 11 pounds) of golden shiners Notemigonus crysoleucas to serve as a gizzard shad surrogate and to help simulate diet composition of cormorants in the field. After protecting half of each of these ponds with netting, one cormorant was allowed to forage from each 0.02 -ha $(0.05$-acre $)$ unprotected pond-half for 10 consecutive days. Cormorant feeding activity in this study was designed to simulate the average number of cormorants (30) observed by Stickley et al. (1992) on a commercial 6-ha (15-acre) pond for 100 days (500 cormorant-days/ha, or ca. 200 cormorant-days/acre). Following the predation period in February, fish were maintained in pond halves for 7.5 months using satiation feeding and were completely inventoried when they reached harvestable size.

The results of this experiment represent the only available information on the effects of cormorant predation on catfish production losses at harvest (Table 16.1). Two ponds experienced severe disease outbreaks that devastated the catfish population ( $>64 \%$ mortality) and did not produce usable data. Two ponds had almost no mortality from disease, and cormorants preying on both catfish and shiners consumed approximately $7 \mathrm{catfish} / \mathrm{bird}$ per day resulting in an average $30 \%$ decline in catfish numbers, relative to inventories from the protected pond halves. At a 
commercial 6-ha (15-acre) pond scale stocked at 12,355 fish/ha (5,000 fish/acre), this might represent a loss of approximately 22,000 fish from 30 cormorants feeding on a pond for 100 days. Because of compensatory growth of fish where predation occurred, this loss of fish represented approximately a $20 \%$ loss in biomass of fish produced, or $6,800 \mathrm{~kg}$ (15,000 pounds) from a commercial pond. In two ponds where moderate ( 24 to $42 \%$ ) disease mortality occurred, cormorants fed almost exclusively on catfish, despite the presence of shiners. Consistent with these observations, cormorants were calculated to consume 9 catfish/bịrd per day, closely paralleling consumption rates of cormorants on an exclusive diet of catfish. Because of this, fish losses due to predation averaged $56 \%$ above the losses caused by disease, and production losses were reduced by $61 \%$. Because surviving fish density was relatively low for both protected and unprotected pond-halves due to disease, there was no conspicuous compensatory growth of fish where predation occurred.

\subsubsection{Economics of depredation}

The economics of cormorant depredations has been approached by several methods and at different scales. At an industry scale, Wywialowski (1999) used a nationwide producer survey to calculate a $\$ 12$ million loss to catfish producers from all wildlife, including cormorants. However, the extent that producers can estimate their loss to cormorants is questionable (Glahn et al. 2002a).

To obtain more objective information on a regional scale, Glahn and Brugger (1995) used bioenergetic modeling to project that cormorants wintering in the catfish production region of northwest Mississippi were costing producers approximately $\$ 2$ million annually. Based on increasing cormorant populations observed in recent years, Glahn et al. (2000b) updated this figure to approximately $\$ 5$ million. However, these losses only considered replacement cost of these fish at the time that predation occurred. Although this may come close to estimating the cost of depredations on fingerling ponds, it does not reflect potential production losses from grow-out ponds at harvest.

Considering a $30 \%$ depredation loss of 75,000 fingerlings from a 6-ha (15-acre) grow-out pond (Glahn and Dorr 2002), the replacement value of these 22,000 fingerlings removed by cormorants has been estimated to be approximately $\$ 2,200$. However, the $20 \%$ biomass loss of these fish at harvest of $6,800 \mathrm{~kg}(15,000$ pounds) would be valued at $\$ 10,500(\$ 1.54 / \mathrm{kg}$, or $\$ 0.70$ /pound), or five times the value of fingerlings lost. Assuming this ratio is approximately correct and that most depredations occur primarily at grow-out ponds, economic losses from cormorant depredations to northwest Mississippi farmers may actually approach $\$ 25$ million; i.e., 5 times replacement cost projections by Glahn et al. (2000a).

To examine economic effects of cormorant depredations on farm profits, Glahn et al. (2002a) developed an enterprise budget that assumed a $20 \%$ production loss from depredation for a 6 -ha (15-acre) pond using a single-batch cropping system stocked with $12,355 \mathrm{fish} / \mathrm{ha}$ ( $5,000 \mathrm{fish} / \mathrm{acre})$ (Table 16.2). Assuming a $20 \%$ reduction in gross revenue from production losses, as well as reductions in costs of feed and harvesting, profits of $\$ 1,189 /$ ha $(\$ 481 /$ acre) without cormorant predation were decreased by $111 \%$, to $-\$ 132 /$ ha $(-\$ 53 /$ acre $)$. Thus, cormorant depredation losses observed under experimental conditions (Glahn and Dorr 2002) can be particularly devastating to farm profits. This is because of rather narrow profit margins in the catfish industry when both variable (e.g., feed) and ownership (e.g., pond maintenance) costs are considered (Table 16.2). 
TABLE 16.2. Enterprise budget with and without cormorant predation simulating 500 cormorant-days/ha for one, 6-ha foodfish pond using a single-batch cropping system stocked at $\mathbf{1 2 , 3 5 5} \mathrm{fish} / \mathrm{ha}$. Other variable costs include the cost of fingerlings, labor, management, tractor fuel and maintenance electricity for aeration, well operation, vehicle repairs and maintenance, disease and predation control, and office costs and supplies. Ownership costs are annual prorated costs of depreciation, interest on investments, taxes and insurance. Source: Glahn et al. (2002a).

\begin{tabular}{lcc}
\hline Item & With predation & Without predation \\
\hline Gross Revenue & $\$ 43,050$ & $\$ 53,550$ \\
Variable costs & 9,906 & 11,615 \\
$\quad$ Feed & 2,460 & 3,060 \\
$\quad$ Harvesting & 2,082 & 2,252 \\
$\quad$ Interest on capital & $\underline{15,778}$ & $\underline{15,778}$ \\
$\quad$ Other variable costs & 30,226 & 32,705 \\
$\quad$ Total variable costs & 12,824 & 20,845 \\
Income above variable costs & $\underline{13,626}$ & 13,626 \\
Ownership costs & 43,852 & 46,331 \\
Total costs & -802 & 7,219 \\
Net return (profits) & & \\
\hline
\end{tabular}

\subsubsection{Prevention and control of depredations}

Alleviating cormorant depredations involves employing one or a combination of three basic strategies: 1) physically separating birds from fish, 2) managing the birds responsible for the damage, and 3) modifying fish culture practices (Glahn et al. 2000a).

Exclusion - the physical separation of birds from the fish-entails erecting and maintaining fences, nets, or other barriers. Although total separation may not be practical, various barrier techniques may serve to limit cormorant access to ponds or to the fish in those ponds (Littauer et al. 1997). Supported netting, the only completely effective method of excluding cormorants, appears impractical because typical catfish farm levees are not wide enough to accommodate support structures and still allow vehicle access (Mott and Boyd 1995). Plastic and wire grids over catfish ponds can deter cormorant flocks from landing and taking off, but do not necessarily exclude individual birds (Barlow and Bock 1984; Moerbeek et al. 1987).

Some success with simple parallel overhead wires, spaced on $8-\mathrm{m}$ (ca. 25-foot) centers have been reported (Davis 1990); but in other studies cormorants simply landed on the levees and walked under the wires into the ponds (Barlow and Bock 1984). Overhead wire systems may be more practical for small ponds. Keller (1999) found that overhead wires, in conjunction with harassment efforts, were effective for protecting smaller (0.2- to 2.5-ha; ca. 0.5 - to 6-acre) ponds from great cormorants Phalacrocorax carbo in Germany, but May and Bodenchuk (1992) concluded that an overhead wire grid structure was impractical for a 3.7-ha (ca. 9-acre) catfish pond under current cultural practices. Although current research may help resolve some of these conflicting results, overhead wires may pose a problem due to interference with harvesting and other cultural practices (Mott and Boyd 1995). Where practical to use, overhead wires should be 
marked with plastic streamers to improve their utility and reduce hazards to cormorants and other avian species that may be injured by these wires (Mott and Boyd 1995).

Possible alternatives to overhead wires include floating ropes and underwater grids. Mott et al. (1993) spaced lengths of 9.5-mm (3/8-inch) polyethylene rope with attached foam floats at $15-$ to $17-\mathrm{m}$ (50- to 55-foot) intervals across two catfish ponds, perpendicular to prevailing winds. This system was effective in deterring cormorant flocks, but not individual birds, for 3 to 8 weeks, and appeared more practical for protecting large ( $>2$ ha; 5acres) ponds than overhead wires. However, the presence of a number of unprotected ponds in the vicinity may have influenced the results (Glahn et al. 2000a). Underwater barriers or baffle systems could theoretically interfere with cormorants' pursuit of catfish (Barlow and Bock 1984), but studies using submerged nets to deter cormorants did not reduce cormorant use of ponds and presumably their depredation of catfish (Gottfried 1998). Although barrier systems may show promise for certain situations, many catfish farmers may find them impractical due to their interference with multi-year harvesting (Mott and Brunson 1995).

Due to the practical limitations of exclusion and barrier techniques, cormorant depredation control has focused almost exclusively on frightening strategies, reinforced with lethal control (Wywialowski 1999). Typically, this involves personnel patrolling pond levees in a vehicle and shooting pyrotechnics and shotguns at birds (Stickley and Andrews 1989). Despite the widespread use of this "harassment patrol" strategy, very little is known about its overall effectiveness in reducing cormorant depredations (Mott and Boyd 1995). In Europe, Moerbeek et al. (1987) found that such frightening strategies were insufficient to deter great cormorants from fish ponds. Similarly, Reinhold and Sloan (1999) reported that cormorants in Mississippi quickly returned to catfish ponds after being harassed or simply moved from pond to pond, negating efforts to reduce depredations.

Supplemental frightening devices, including propane cannons, recorded distress calls, sirens, and particularly human effigies, can enhance the effectiveness of harassment patrols (Littauer et al. 1997). For instance, Stickley et al. (1995) found that an electronically inflatable human effigy, used in conjunction with harassment patrols, caused a dramatic reduction of cormorant numbers on ponds. Similarly, A. R. Stickley (USDA-National Wildlife Research Center, Mississippi State, Mississippi, unpublished report) observed more than $90 \%$ reduction in cormorant numbers on ponds when inexpensive stationary human effigies, periodically replaced by shooters, were used to supplement harassment patrols. Regardless of supplemental techniques used, cormorant harassment programs must be consistent and aggressive to be effective (Littauer et al. 1997). Starting harassment early in the fall and moving supplemental devices often is also recommended (Littauer et al. 1997). Automation of cormorant harassment is not possible with passive devices such as propane cannons alone (Littauer et al. 1997); but in the future some automation might be accomplished by frightening devices that are remotely triggered by farm personnel or the birds themselves (Larry Clark, USDA-National Wildlife Research Center, Fort Collins, Colorado, personal communication ). Despite possible improvements in harassment procedures, cormorants can quickly habituate to frightening devices that provide no negative reinforcement.

To reinforce harassment patrols, limited killing of birds has often been recommended as part of an integrated damage management plan (Hess 1994; Mastrangelo et al. 1995; Littauer et al. 1997). Although the take of cormorants was previously limited under depredation permits issued by the U.S. Fish and Wildlife Service, catfish farmers, in consultation with USDA/Wildlife Services, are now allowed to shoot an unlimited number of cormorants at their farms under a depredation order issued by the U.S. Fish and Wildlife Service in March 1998 (USDI-FWS 1998). 
Limited information exists as to the effectiveness of unlimited lethal control in reducing depredations. However, Hess (1994) evaluated the unlimited take of cormorants at several catfish farms and found that only 290 cormorants were killed by farm personnel in over 3,000 personhours of shooting. He attributed the low rate of kill to cormorants learning to avoid being shot and reported that fewer cormorants attempted to use pond complexes where shooting was deployed. To increase the take of cormorants and presumably increase the effectiveness of shooting for reducing depredations, the cormorant depredation order allows catfish farmers to implement strategies similar to those used by waterfowl hunters, such as using decoys, blinds and camouflaged clothing (USDI-FWS 1998). Employing such tactics might enable farmers to reduce cormorant depredations at their farms, but has never been evaluated. However, such tactics, particularly the use of decoys, have been effective in luring cormorants within shotgun range (Glahn et al. 1995).

Coordinated dispersal of cormorant night roosts has been used to redistribute roosting cormorants away from the catfish production region of northwest Mississippi (Glahn et al. $2000 \mathrm{~b}$ ). Roost dispersal involves simultaneous harassment of all known night roost sites impacting catfish production areas and is coordinated by USDA/Wildlife Services (Reinhold and Sloan 1999). Catfish farmers are assigned to all known roost sites and they fire pyrotechnics as cormorants enter the roost in the evening for three consecutive nights, or until the roost is dispersed (Reinhold and Sloan 1999). Although shooting in roosts can be equally effective as pyrotechnics for dispersing cormorants (Glahn 2000), it is not currently authorized under the cormorant depredation order (USDI-FWS 1998). However, low-powered lasers are also effective in dispersing cormorants from their night roosts (Glahn et al. 2001) and can be used as an alternative to pyrotechnics where disturbance of other wildlife is a concern.

Several studies evaluating night roost harassment indicate that cormorants temporarily shift their roosting activity from harassed sites and relocate to areas where they normally cause less damage (Mott et al. 1998; Glahn et al. 2000b). In response to shifting roosting populations, cormorants observed in the vicinity of catfish ponds have been reduced by 70 to $90 \%$ (Mott et al. 1991; Mott et al. 1998). However, these reductions are only temporary and roost harassment must be repeated regularly throughout the winter (Reinhold and Sloan 1999; Glahn et al. 2000b). Although night roost dispersal of cormorants does not eliminate the need to harass cormorants from catfish ponds, it can substantially reduce the amount of harassment effort needed on farms where birds from nearby roosts are causing severe problems (Mott et al. 1998). Logistic limitations and the need for extensive coordination may limit the utility of this procedure in other catfish producing regions (Reinhold and Sloan 1999). An initial assessment of the extent and proximity of alternative roosting habitat to catfish production areas is needed to determine whether roost harassment programs may be logistically practical to implement (Mott et al. 1998). In northwest Mississippi, the doubling of the cormorant population in recent years and a similar increase in the number of known roost sites has made it increasingly difficult to maintain an effective coordinated roost dispersal program. This has required a substantial increase in effort to maintain cormorant numbers in the protected area at levels equaling those recorded before the start of roost harassment efforts (Glahn et al. 2000b).

Because of the negative effects of increasing cormorant populations and the limited effectiveness of present damage management efforts, proposed strategies for managing various cormorant depredations have focused on reducing cormorant populations to biologically and socially acceptable levels (Reinhold and Sloan 1999; Glahn et al. 2000a). Glahn et al. (2000a) suggest that reducing or stabilizing cormorant populations to preset population goals will require 
more intensive control on the wintering grounds (i.e., culling adult birds in roosts), control on the breeding grounds (i.e., egg oiling and culling adults), or a combination of both. However, credible management of cormorant populations will benefit from the development of a population dynamics model that will predict the type and extent of control needed to reduce cormorant populations impacting the catfish industry and still maintain viable cormorant populations (Glahn et al. 2000a). The benefits of managing cormorant populations should be based on alleviating damage (Werner 2000), but are difficult to predict. Managing cormorant populations is unlikely to be a panacea for resolving cormorant depredations on catfish. Instead, it should be viewed as a means of enhancing or restoring the effectiveness of current damage management strategies (Glahn et al. 2000a).

With methods of alleviating cormorant depredations focused largely on managing either cormorant populations or their foraging activity on catfish ponds, little information exists on the effects of altering catfish culturing practices to reduce depredation losses. However, a number of possible alternatives have been proposed by several authors (Barlow and Bock 1984; Moerbeek et al. 1987; Mott and Boyd 1995). These include reducing pond size, delaying stocking, and reducing stocking rates. Reducing pond size would help facilitate installation and maintenance of bird exclusion structures, but is impractical because most ponds have already been constructed (Glahn et al. 2002a). Mott and Boyd (1995) recommend locating fingerling ponds or other ponds especially susceptible to depredations near areas with the most human activity (e.g., farm shops and offices). This would capitalize on the natural fear that cormorants have for humans and facilitate harassment of birds on these ponds.

Delaying stocking of fingerlings into grow-out ponds would allow more concentrated birdcontrol efforts at fewer fingerling ponds. By not stocking fingerlings into grow-out ponds during the winter months (November to mid-April), food-fish producers would avoid almost the entire period of cormorant predation (Glahn et al. 1995) during a period when catfish are not likely to grow appreciably (Tucker and Robinson 1990). However, delayed stocking may be inconsistent with multiple-batch cropping systems that are prevalent within the catfish industry (Tucker and Robinson 1990).

Reducing stocking rates has been suggested as a means of reducing cormorant foraging efficiency (Barlow and Bock 1984) which, in turn, could reduce the attractiveness of catfish ponds (Mott and Boyd 1995). Conversely, higher stocking rates, which are clearly the industry trend (CEAH 1997b), may mitigate the effects of cormorant predation on catfish production. Glahn et al. (2002a) adapted pond production data from studies where research ponds stocked with either 18,500 fish/ha (ca. 7,500 fish/acre) or 25,000 fish/ha (ca. 10,000 fish per acre) incurred a range of fingerling mortalities. They assumed that cormorants were responsible for all observed mortalities and consumed catfish at an average rate of 7 catfish/bird per day, and used a regression model to predict the effects of cormorant use of ponds (cormorant-days/ha) on catfish production (Fig. 16.2). Considering that cormorant use of these more densely stocked ponds would remain comparable to that of ponds stocked at lower rates ( 500 cormorant-days/ha), cormorant losses would be proportionally lower and have less effect on production at harvest (Glahn et al. 2002a).

Other practices suggested to reduce cormorant depredations include the use of "buffer prey" to deflect predation from catfish and the addition of pond dyes to reduce the visibility of fish during cormorant pursuit (Mott and Boyd 1995). Stickley et al. (1992) noticed that cormorants foraging in one catfish pond appeared to prefer wild gizzard shad, which were more easily manipulated and swallowed than catfish. However, subsequent controlled studies with captive 


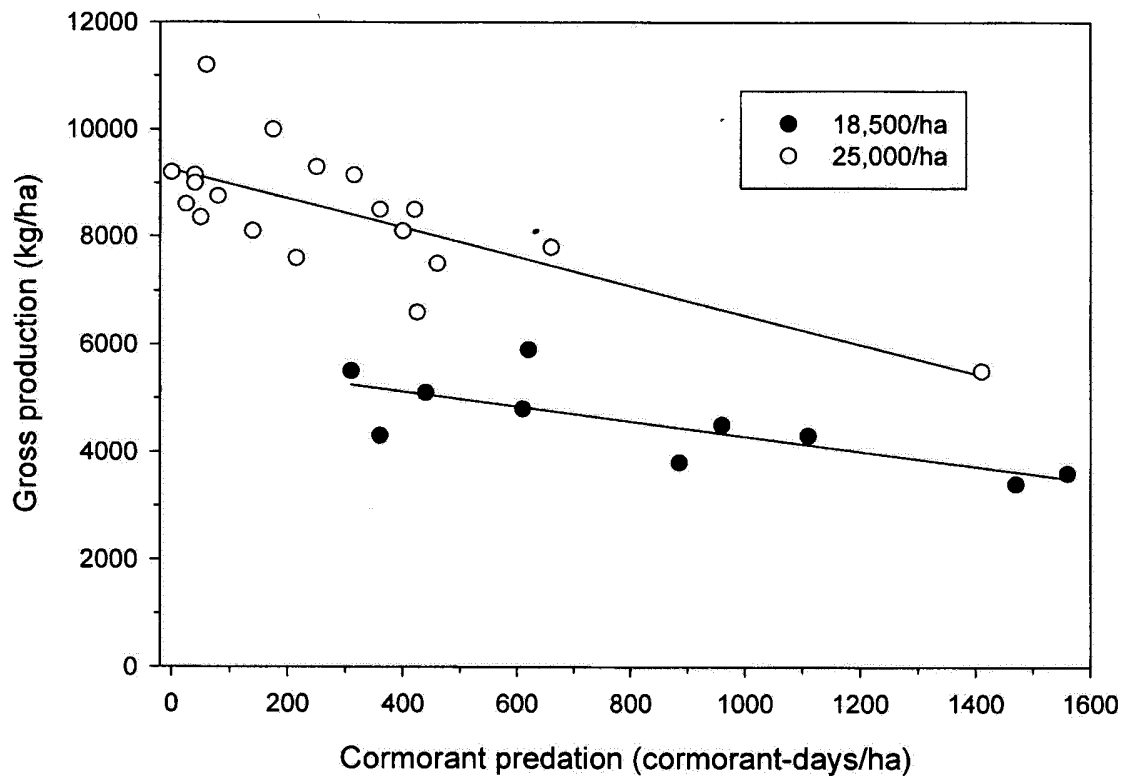

FIGURE 16.2. Relationship between simulated cormorant predation (cormorant-days/ha) and gross catfish production $(\mathrm{kg} / \mathrm{ha}$ ) in research ponds stocked with 18,500 or 25,000 fish/ha (Hanson and Li, unpublished data). Cormorant-days/ha were calculated from observed mortalities assuming that cormorants remove 7 catfish/bird per day (Glahn et al. 2002a).

comorants suggest that despite "buffer prey" having some benefits in reducing production losses, cormorants exhibited no preference for more readily-manipulated buffer prey (i.e., golden shiners) (Glahn and Dorr 2002). Even if preferred "buffer prey" could be identified, use of buffer prey to reduce cormorant depredations on catfish remains controversial because of the possibility that more attractive prey in catfish ponds may simply attract more cormorants (Mott and Boyd 1995). Along similar lines, some authors (Erwin 1995; Mott and Boyd 1995) suggest the development of alternative foraging sites stocked with preferred buffer prey. However, the effectiveness of such a procedure would rely heavily on maintaining a density of buffer prey that would not be quickly depleted by cormorant populations foraging in the area (Glahn et al. 2000a). The use of pond dyes has been recommended to reduce the visibility of fish to cormorants (Mott and Boyd 1995), but has never been evaluated. However, the natural turbidity (Secchi disk readings less than $40 \mathrm{~cm}$ ) of most catfish ponds suggests that cormorants do not require good visibility to pursue and capture catfish (Glahn et al. 2000a).

With the exception of total exclusion with netting, no single control strategy is likely to reduce cormorant depredations on catfish to acceptable levels (Mott and Boyd 1995). Where practical, combining strategies would most likely be the best approach. For instance, a catfish farmer might delay stocking fingerlings into grow-out ponds and use overhead wires, floating ropes and other barriers in combination with intensive harassment patrols of fingerling ponds and nearby roosts. As cormorant problems intensify and the need to stock fingerlings becomes 
apparent, the same farmer may wish to shift to more aggressive farm-wide harassment of cormorants, combined with an intensive lethal control program to supplement harassment activities.

\subsubsection{Costs and benefits of control}

The costs and benefits of control methods used to reduce cormorant depredations vary considerably. Typically, exclusion and barrier systems have the largest costs, but have longer-term benefits. Supported netting is the only completely effective, long-term solution to excluding cormorants from ponds, but is economically impractical. Littauer et al. (1997) estimated that it would cost approximately $\$ 1$ million to enclose 40 ha (ca. 100 acres) of ponds. Although overhead wires are somewhat less effective than netting, costs are lower, and such systems may be cost-effective for protecting smaller ponds. Keller (1999) found that overhead wires spaced $7.5 \mathrm{~m}$ (ca. $25 \mathrm{feet})$ apart were cost-effective in protecting smaller ( 0.2 to $2.5 \mathrm{ha} ; 0.5$ to 6 acre $)$ ponds from cormorant predation in Germany when prorated over the 10-year life span of the system. Because some cormorants may learn to evade widely spaced wire systems (Moerbeek et al. 1987; Keller 1999), additional costs of frightening devices may also be realized.

Although the costs of deploying frightening and lethal control strategies are typically less than exclusion and barriers, the need for almost continuous harassment of birds by one or more personnel over an increasingly long wintering period can be costly. Littuaer et al. (1997) calculated the costs (labor and materials) of deploying a frightening program on a farm 200 ha (ca. 500 acres) or less to be $\$ 20,000$ over a 5-month period. Also, Wywialowski (1999) reported that Mississippi catfish producers on average spent almost $\$ 9,000 /$ year for wildlife damage control and that control costs varied with catfish sales. Considering cormorant depredation losses estimated from observations, Stickley et al. (1992) concluded that efforts to repel cormorants from ponds were well justified and economically reasonable based on replacement costs of catfish alone. Assuming harassment patrols are effective in depredations, a more recent economic analysis confirms this conclusion (Glahn et al. 2002a). The benefit of shooting an unlimited number of cormorants, as permitted under the depredation order, has not been thoroughly assessed. However, Hess (1994) found that cost-effectiveness varied among pond complexes and was greatest where there were large numbers of cormorants in the vicinity of ponds.

Relative to the costs of harassing cormorants on ponds, the costs to farmers of cormorant dispersal programs are relatively small. Based on costs of pyrotechnics and labor, the total costs of roost dispersal programs were \$16,757 and \$32,303 during the winters of 1993-94 and 1994-95, respectively (Mott et al. 1998). However, the average cost to each participating catfish producer was only $\$ 419$ and $\$ 557$, respectively. Although cormorant roost dispersal does not eliminate the need to harass cormorants from ponds, because of it, the costs of harassment on ponds are reduced (Mott et al. 1998). Compared to costs of harassing cormorants from ponds before roost dispersal programs began, catfish producers in areas where cormorants were dispersed reported average annual savings of $\$ 1,406$ and $\$ 3,217$ in the winters of 1993-94 and 1994-95, respectively. Thus, roost dispersal programs appeared to be cost-effective in those years. However, increasing cormorant populations, combined with increasing numbers of known roost sites have resulted in increased costs of implementing this program and diminished its benefits (Glahn et al. 2000b).

Costs of implementing changes in culture practices vary greatly and their benefits in reducing cormorant depredations are sometimes unclear. Some costs may be very high with doubtful benefits. For example, reducing pond size might facilitate installing bird exclusion systems; 
however, pond construction cost, a major capital expenditure, increases as pond size decreases (Garrard et al. 1990). Although the average size of newly constructed ponds has decreased slightly from 6 ha to 4.8 ha (Terrill Hanson, Mississippi State University, unpublished report), there is no information to suggest that ponds of 4 to 5 ha (ca. 10 to 12 acres) are small enough to make exclusion barriers practical. In contrast, delaying stocking of fingerlings into grow-out ponds may have no associated costs because of the limited growth of these fish during winter months (Tucker and Robinson 1990). However, delaying.stocking until late spring after cormorants leave may increase the risk of stress-related disease outbreaks (Glahn et al. 2000a).

Decreasing stocking rates of ponds might reduce the attractiveness of ponds to cormorants, but is counterintuitive to improving net returns. Increased stocking rates (up to 25,000 fish/ha; ca. 10,000 fish/acre) has become a potentially cost-effective means to improve yields, since the costs of additional fingerlings have remained relatively low (Engle and Kouka 1996). This trend continues despite research suggesting that increased stocking rates do not necessarily increase net returns (Tucker et al. 1992). Although water quality problems and associated disease outbreaks may be closely associated with stocking density (Tucker et al. 1992), there is no evidence that cormorant depredation problems are associated with stocking density or other culture practices (Brian Dorr, USDA-National Wildlife Research Center, Mississippi State, Mississippi, personal communication). If cormorant depredations remain constant at various stocking densities, then limited data from research ponds suggest that catfish production from ponds stocked at either $18,500$ to $25,000 \mathrm{fish} / \mathrm{ha}$ ( 7,500 to $10,000 \mathrm{fish} /$ acre $)$ would not be negatively impacted at calculated depredation rates simulating 30 cormorants foraging on a pond for 100 days (Glahn et al. 2002a). However, further research is needed to determine optimal stocking rates with respect to cormorant depredations that maintain acceptable profit margins (Glahn et al. 2002a).

\subsection{WADING BIRDS}

Wading birds include several species of long-legged wetland birds that have long been implicated in depredation problems to aquaculture in the United States (Cottam and Uhler 1945) and Europe (Draulins 1988). In addition to catfish, these problems have been associated with depredations on trout (Parkhurst et al. 1992; Pitt and Conover 1996; Glahn et al. 1999a), bait fish (Hoy et al. 1989), and ornamental fish (Avery et al. 1999). The two primary species implicated in depredations on catfish are the great blue heron Ardea herodius and the great egret Ardea alba (Hodges 1989; Ross 1994; Glahn et al. 1999b). Snowy egrets Egretta thula, little blue herons Egretta caerulea, black-crowned night herons Nycticorax nycticorax, and wood storks Mycteria americana have been infrequently observed at catfish farms (Glahn et al. 1999b), but there is no evidence to suggest that they cause any significant losses of catfish. This is particularly true of the cattle egret Bubulcus ibis, which may frequent catfish farms but does not feed on fish (Stickley 1990).

\subsubsection{Identification and biology}

The great blue heron (Fig. 16.3) and the great egret (Fig. 16.4) exceed $1 \mathrm{~m}$ (ca. 3 feet) in height and except for the wood stork, are the largest wading birds observed at catfish farms. The great blue heron is slate-blue in color and may have a black and white head. The great egret is all white in color with a yellow bill and black legs. In contrast, the wood stork is white with black wings 


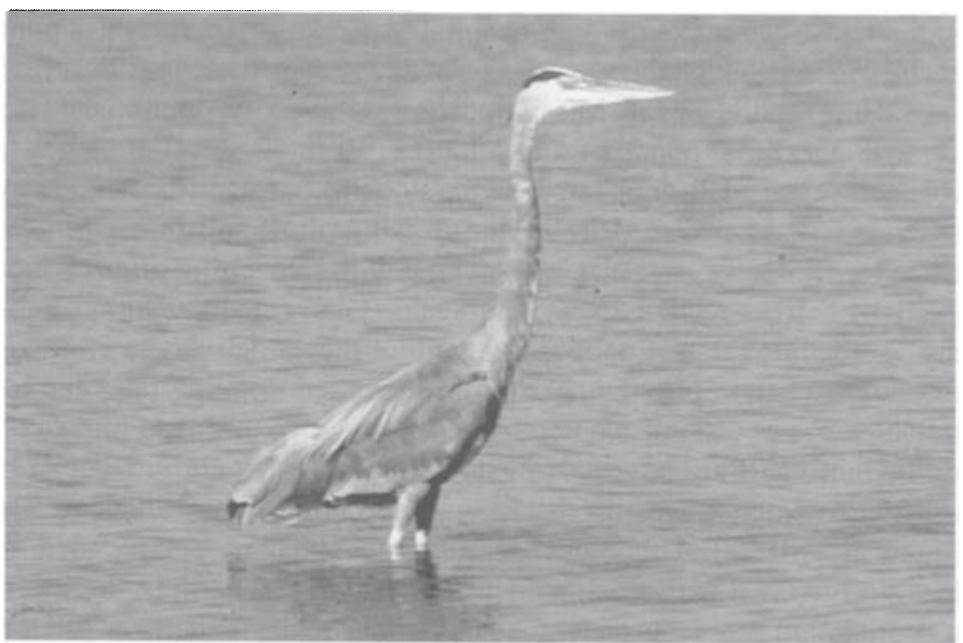

FIGURE 16.3. Great blue heron.

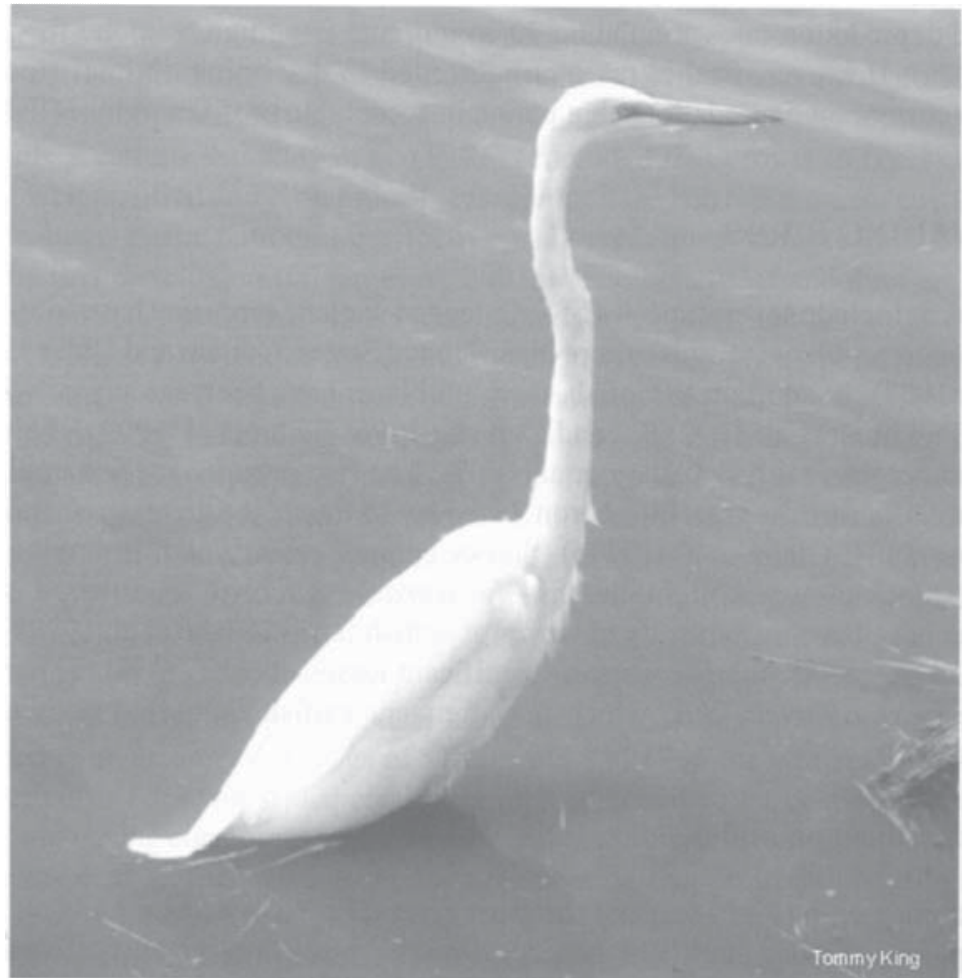

FIGURE 16.4. Great egret. 
and tail. Unlike the great blue heron and great egret, the wood stork has a broad curved bill. Identifying characteristics of these and smaller herons and egrets were summarized by Stickley (1990).

Great blue herons (hereafter called herons) and great egrets (hereafter called egrets) are visual foragers and forage on catfish ponds almost exclusively during daylight hours, despite some herons being present at night (Stickley et al. 1995; Glahn et al. 1999b). Herons and egrets typically stand and wait, or walk along pond ędges to obtain fish prey that occurs in the littoral zones of lakes and ponds (Willard 1977). However, both species are known to use a variety of behaviors, including landing in the middle of catfish ponds, to obtain fish (Ross 1994). Although herons sometimes forage alone, egrets are gregarious and large aggregations of both species form at sites with high prey availability (Kushlan 1976). In murky-water situations like catfish ponds, prey availability increases when conditions exist that bring fish close to the surface (Glahn et al. 2001). However, low-water situations, which most often occur in watershed ponds, may also increase prey availability to wading birds (Kushlan 1976).

\subsubsection{Distribution and numbers}

Herons and egrets are the most widely occurring fish-eating birds at most catfish farms and occur on the ponds throughout most of the year. Glahn et al. (1999b) found wading birds present at 59 of $67(88 \%)$ randomly sampled catfish pond complexes in northwest Mississippi. Numbers of herons and egrets varied with location, season, and time of day, but in 1996 the average 127-ha (315-acre) catfish farm in northwest Mississippi was estimated to support about 78 herons and 56 egrets. At these densities, populations at all catfish farms in northwest Mississippi was estimated at approximately 25,000 herons and 18,000 egrets (Glahn et al. 1999b). Compared to heron survey results from some of the same complexes in 1990, heron populations at these farms had increased eightfold (Glahn et al. 1999b).

Heron abundance on catfish ponds is typically low ( 0 to 3 birds/pond), but herons concentrate at ponds where fish are diseased and where fish are being fed (Glahn et al. 2002b). Disease and fish-feeding bring catfish to the surface where they are more vulnerable to heron predation. Similarly, egrets appear to be most attracted to fingerling ponds where fish are dying (Hodges 1989).

\subsubsection{Diet and depredation problems}

Consistent with the wide distribution of herons at catfish farms, $42 \%$ of catfish farmers responding to a nationwide survey reported that herons cause depredations on their fish stocks (Wywialowski 1999). However, only $16 \%$ of the same producers cited egrets as a problem. Similarly, when 47 catfish farm managers were asked to rank the importance of avian predators at their farms, $81 \%$ ranked the great egret third after the cormorant and great blue heron (Glahn et al. 1999b). Thus, catfish farmers perceive egrets to be less of a problem than herons. In fact, studies of the diet and foraging behavior of both herons and egrets raise some questions regarding the extent of their depredations at catfish farms.

Herons and egrets are primarily fish-eating birds but eat a variety of vertebrate and invertebrate prey (Cottam and Uhler 1945). At catfish farms in Mississippi, most of the heron diet consisted of wild sunfish Lepomis spp., gizzard shad, and mosquito fish Gambusia spp. (Stickley et al. 1995). Based on observations, the heron diet consisted of $44 \%$ by weight of live catfish 


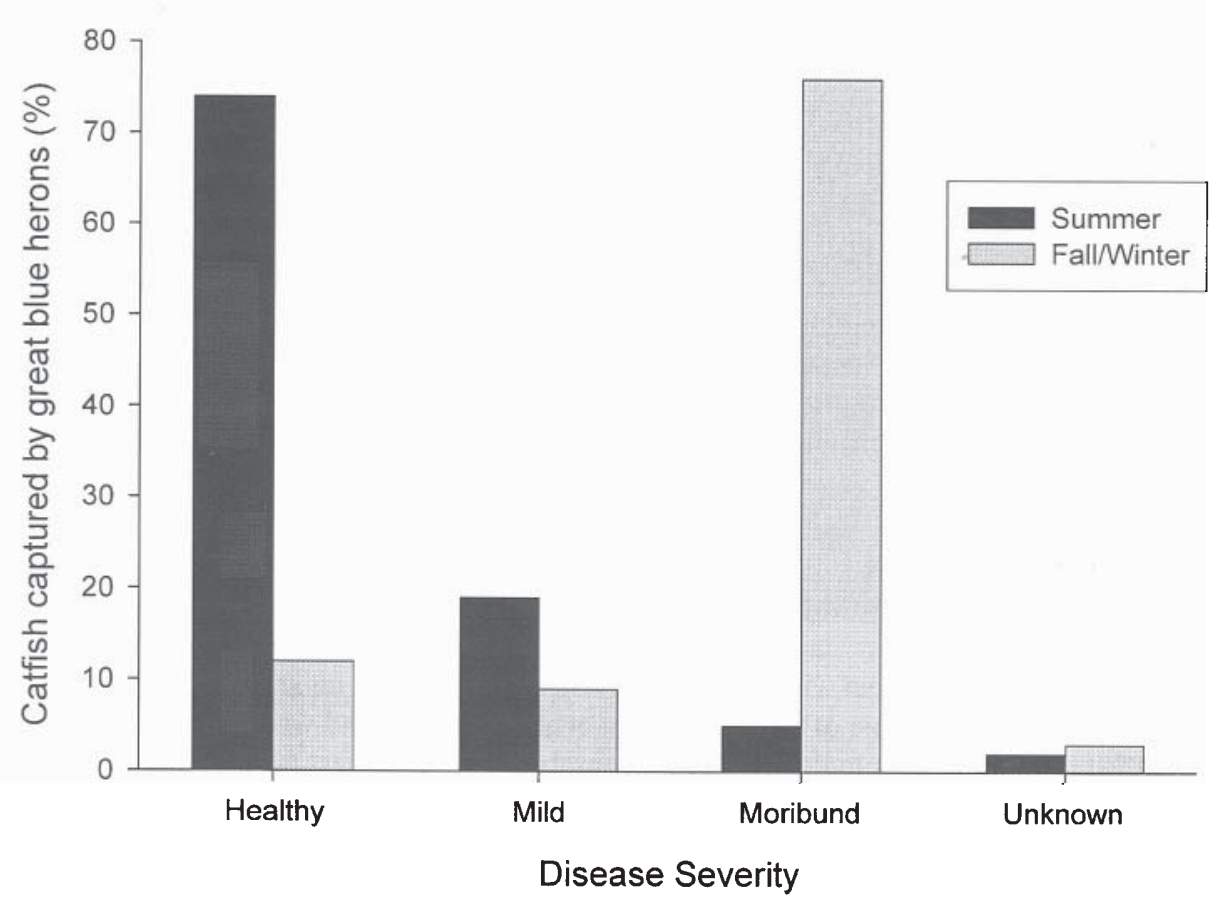

FIGURE 16.5. Percentage of catfish clinically diagnosed by disease category that had been captured by great blue herons from selected catfish ponds in northwest Mississippi where herons were concentrated ( $\geq 6$ birds) during the fall and winter of $1998(n=55)$ or where herons took catfish from ponds during the summer of 1998 and $1999(n=63)($ Glahn et al. 2002b).

averaging approximately $15 \mathrm{~cm}$ ( 6 inches) (Glahn et al. 1999b). The remaining diet consisted of dead catfish and wild fish. The diet of egrets contained even fewer ( 28 to $35 \%$ by weight) catfish, averaging $10 \mathrm{~cm}$ (4 inches) in length (Ross 1994; Glahn et al. 1999b). However, only $8 \%$ of the diet was judged to be live catfish (Glahn et al. 1999b). The size of catfish consumed is consistent with observations suggesting that egrets forage primarily at fingerling ponds (Hodges 1989; Glahn et al. 1999b). Most of the catfish consumed by herons and egrets are taken in the spring or fall when catfish diseases are common (Stickley et al. 1995; Glahn et al. 1999b). This is consistent with a recent study (Glahn et al. 2002b) indicating that $85 \%$ of live catfish captured by herons congregating at ponds in the fall and winter were diseased and $76 \%$ were judged by a pathologist to be terminally ill (Fig. 16.5). In contrast, most (75\%) of the live catfish consumed by herons at ponds where catfish were being fed were healthy (Fig. 16.5). At times other than during fish feeding, studies of captive herons suggest that they are inefficient at capturing healthy catfish and may survive primarily on diseased catfish and wild fish in ponds (Glahn et al. 2000c).

Because herons and egrets prey on large numbers of diseased and dead catfish, these birds could transmit disease organisms from one pond to another. Taylor (1992) identified the bacterium Edwardsiella ictaluri-responsible for enteric septicemia of catfish (ESC) - from both 
herons and egrets. However, Waterstrat et al. (1999) were unable to culture viable ESC organisms from fecal samples of herons repeatedly fed catfish fingerlings that had been injected with high concentrations of ESC organisms. High body temperatures $\left(41^{\circ} \mathrm{C} ; 106^{\circ} \mathrm{F}\right.$ ) of herons (Waterstrat et al. 1999) and egrets (J. F. Glahn, USDA-National Wildlife Research Center, Mississippi State, Mississippi, unpublished data) suppressed the growth of the E. ictaluri in the gastrointestinal tract of these birds, thus limiting their role in disease transmission among ponds (Waterstrat et al. 1999). Because major catfish diseases such as ESC and columnaris are caused by organisms that are ubiquitous in ponds and fish populations in the lower Mississippi Valley, their transmission by birds is probably not a major factor in the spread and severity of disease within the catfish industry (Tucker and Robinson 1990; Taylor 1992). However, this may not be the case with parasitic diseases such as proliferative gill disease, and further research is needed to clarify the role of birds as disease vectors.

\subsubsection{Economics of depredation}

Estimates of the economic impact of heron and egret depredations have been largely based on daily rates of live catfish consumed, assuming replacement costs of catfish obtained from fingerling ponds (Glahn et al. 1999b; Glahn et al. 2002b). Based on energetic models, herons consume approximately $300 \mathrm{~g}$ ( 0.67 pounds) of fish/bird per day (Schramm et al. 1987; Bennet 1993) and these estimates have been confirmed in captive feeding trials with catfish as prey (Glahn et al. 2000c). From this daily consumption rate and a diet of $41 \%$ catfish, Stickley et al. (1995) calculated that herons consumed $123 \mathrm{~g}$ ( 0.3 pounds $)$ of catfish/day or about $12,10 \mathrm{~g}$ fingerlings/day. Based on observing an average of 22 herons per 126-ha (ca. 315-acre) farm, Stickley et al. (1995) calculated a maximum replacement cost for a farm this size to be $\$ 3,800 /$ year. Corresponding with the increase in heron populations at Mississippi catfish farms in 1996, Glahn et al. (1999b) updated this figure to $\$ 11,400 /$ year. Such loss estimates assume that fingerlings consumed by birds would not have died from other causes. Contrary to this notion, however, recent studies indicate that most catfish consumed by herons were diseased and would have died anyway (Glahn et al. 2002b). This finding is consistent with studies of captive herons foraging on research ponds suggesting a minimal impact on fingerling catfish production from heron foraging activity (Glahn et al. 2000c). The exception is heron depredation activity during times when catfish are being fed. However, the seasonal occurrence of fish feeding, combined with the brief time that fish come to the surface to feed, limit the extent of depredations. Based on heron numbers and their consumption rate of live catfish at these times, Glahn et al. (2002b) projected an annual loss per pond of only 575 fish or less than $1 \%$ of catfish populations in either grow-out or fingerling ponds.

Although the economic impact of egret depredations has not been extensively studied, it is most likely less than that caused by herons because of several factors. Egrets weigh only about half that of herons and, based on energetic demands, would require only $169 \mathrm{~g}(0.42$ pounds) of fish/bird per day (Schramm et al. 1987). However, their diet appears to be comprised of only $8 \%$ live catfish, the remainder being wild fish and dead catfish. Based on field observations, Glahn et al. (1999b) estimated that egrets might be consuming 4.5 fingerlings/day. Considering the average egret density of 56 birds/farm in 1996, egrets were estimated to consume approximately 92,000 fingerlings valued at approximately $\$ 3,700$ (Glahn et al. 1999b). Like herons, egrets are likely to consume diseased fish that may die anyway (Hodges 1989; Glahn et al. 1999b). Thus, their economic impact is probably negligible. 


\subsubsection{Prevention and control of depredations}

Catfish farmers primarily use shooting, vehicle patrols, and other scare tactics to keep wading birds from their ponds (Glahn et al. 1999b). However, wading birds can become resident at farms and quickly habituate to scare tactics (Hodges 1989). Thus, limited killing of birds may be necessary to reinforce scare tactics (Mastrangelo et al. 1995). Catfish farmers must obtain a depredation permit through the U.S. Fish and Wildlife Service to shoot wading birds. Before obtaining a kill permit, farmers must first contact USDA/Wildlife Services personnel to verify that a depredation problem exists and that non-lethal methods have been attempted (Mastrangelo et al. 1995).

Where depredation problems persist, perimeter barriers have been recommended for resolving wading bird problems (Littuaer et al. 1997). However, these systems have produced variable results and do not prevent these birds from taking fish by landing in the pond or taking fish on the wing (Ross 1994). Although perimeter netting has been recommended to exclude wading birds from the littoral zone, in one field trial, herons adapted to this by walking on and foraging from the net (Littuaer et al. 1997). A better perimeter barrier might be electric fencing. A simple two-strand electric fence set up around five catfish ponds reduced wading bird activity by $91 \%$ (Mott and Flynt 1995). The possible key to the effectiveness of this system is that birds shocked by the fence became conditioned to avoid the ponds (Mott and Flynt 1995).

Good management practices, combined with limited strategic harassment efforts, can alleviate most wading bird problems. Maintaining good water quality and reducing stress factors on fish will reduce disease problems that appear to attract wading birds (Hodges 1989; Glahn et al. $2002 \mathrm{~b}$ ). Good management includes sufficient aeration so that fish are not forced close to the surface where they are vulnerable to predation (Glahn et al. 2000c; 2002b). At watershed ponds, maintaining a minimum water depth of at least $1 \mathrm{~m}$ will also limit exposure of fish to predation. Because fish are also vulnerable during fish feeding, strategic harassment of wading birds may be needed at these times (Glahn et al. 2002b). Although not a recommended feeding practice in the long-term (Tucker and Robinson 1990), temporary use of sinking feed might be considered for dealing with persistent wading bird depredations during fish feeding. Clearly, if wading birds are congregating around selected ponds at times other than fish feeding, catfish farmers are best advised to check these ponds for possible disease and water quality problems and to resolve these problems first.

\subsubsection{Costs and benefits of control}

In a limited survey in 1996, catfish farmers in northwest Mississippi reported spending $\$ 4,000$ annually to reduce wading bird depredations using scare tactics (Glahn et al. 1999b). Although this is only half of the cost farmers spend in harassing cormorants (Mott et al. 1998), it may not be justified considering that depredation losses, for the most part, appear negligible (Glahn et al. $2000 \mathrm{~b}$ ). However, in instances where wading birds congregate around ponds during fish feeding, limited harassment may be cost-effective (Glahn et al. 2002b). In other instances where deterring wading birds from selected ponds is justified over longer periods (i.e., fear of disease transmission), use of electric fencing may be more cost-effective than repeated use of scare tactics. In 1992, cost of fencing materials was only $\$ 404$ to exclude birds from a 2.2- ha (5.4-acre) pond and required only 6 person-hours to set up (Mott and Flynt 1995). 

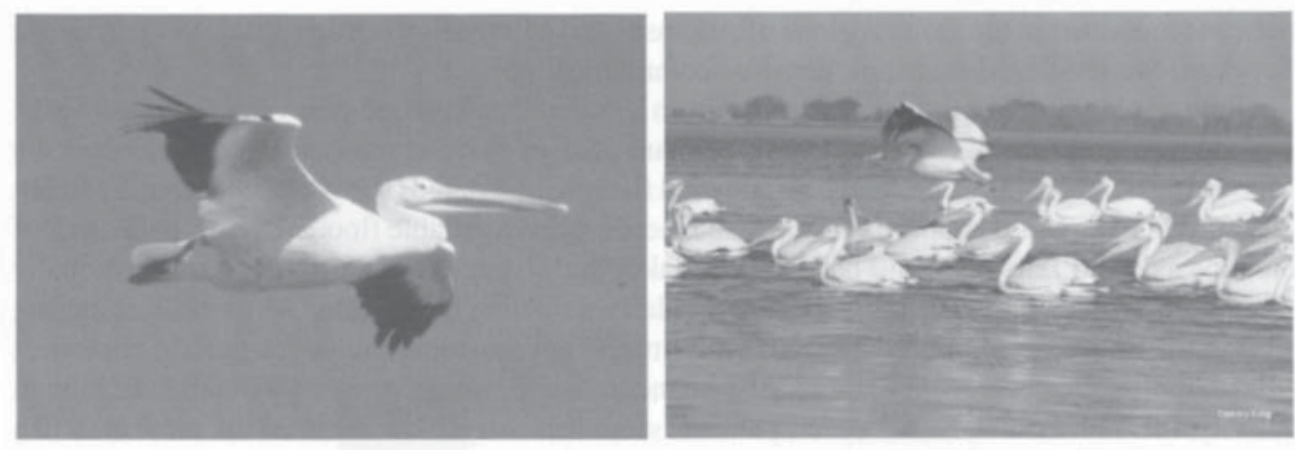

FIGURE 16.6. American white pelican.

With the exception of depredations during fish feeding, wading birds may not be detrimental to catfish aquaculture. In fact, on ponds with a diseased population of catfish, they may be beneficial by selectively feeding on moribund fish and reducing the number of infected fish in the pond (Waterstrat et al. 1999). In these situations harassing birds from infected ponds could prove detrimental if birds disperse disease organisms to surrounding ponds (Glahn et al. 2002b).

\subsection{AMERICAN WHITE PELICANS}

In 1990, Wildlife Services offices in Arkansas, Louisiana, and Mississippi began receiving complaints concerning American white pelicans Pelecanus erythrorhynchos foraging in catfish ponds (King 1995). Although the brown pelican Pelecanus occidentalis has not been reported foraging at inland aquaculture facilities, it has been observed foraging in coastal aquaculture settings (Tommy King, USDA-National Wildlife Research Center, Mississippi State, Mississippi, unpublished data). American white pelicans (hereafter pelicans) come into conflict with southeastern aquaculture by exploiting this abundant and readily available food source while possibly serving as a vector for disease transmission (King 1995).

\subsubsection{Identification and biology}

In contrast to the brown pelican, American white pelicans (Fig. 16.6) are mostly white. Only the primaries and secondaries (flight feathers) are black. The bill and legs vary in color with age. Young pelicans have pale, gray-pink bills and legs while adults have yellow to orange-red bills and legs. During the breeding season, adult pelicans develop a horny knob on the culmen (bill) and pale, yellowish feathers on the chest and upper wing. With a wing span up to $290 \mathrm{~cm}$ (ca. 9.5 feet) and a mean body weight of $6.3 \mathrm{~kg}$ (ca. 14 pounds), the American white pelican is the largest fish-eating bird in North America (Johnsgard 1993).

Pelicans are usually present in the southeastern United States from November through May (King 1995; King and Michot 2002), but since 1995 several hundred pelicans have remained in Louisiana and Mississippi until late June. During the summers of 2000 through 2003, about 1,800 
pelicans remained in the Delta regions of Arkansas and Mississippi (Greg Ellis, USDA-Wildlife Services, Stoneville, Mississippi, personal communication).

Pelicans loaf in groups that vary in size from less than one hundred to several thousand birds. In Arkansas and northwest Mississippi, pelicans loaf in flooded agricultural fields when the Mississippi River is high and sand bars and mud flats are inundated (King 1995; King and Michot 2002). When the Mississippi River is low and there are few available flooded fields, pelicans loaf on exposed mud flats and sand bars in large lakes and rivers. Agricultural fields, intentionally flooded for wintering waterfowl, seem particularly attractive to pelicans. Most pelican loafing sites in the Southeast are open flat areas with little, if any, surrounding vegetation. In northwest Mississippi, pelicans are wary and usually abandon loafing sites disturbed by increased human activity. In south Louisiana, however, pelicans seem less wary and have used the same crawfish pond levees as loafing sites for the past several years, despite human activity (King 1995; King and Michot 2002).

American white pelicans are diurnal and nocturnal foragers (King 1995). However, pelicans in south Louisiana and northwest Mississippi forage primarily during the morning and afternoon (King and Werner 2001). Pelicans feed singly, in small groups ( 2 to 25 birds), or in large groups of more than 25 birds (King 1995). When foraging singly or in small groups, pelicans usually dip their bills to search for food as they swim. When cooperatively foraging, pelicans herd their prey toward shallow water by swimming side by side and synchronously dipping their bills (Anderson 1987; Hart 1989; McMahon and Evans 1992; Johnsgard 1993). Pelicans have been known to fly up to $305 \mathrm{~km}$ (190 miles) from a breeding colony to a feeding site (Johnson 1976) and prefer to forage in shallow water (Anderson 1987; Johnsgard 1993). Due to the relatively shallow water depth and high fish stocking densities, catfish ponds provide a nearly perfect foraging environment for pelicans (King 1995).

In south Louisiana and northwest Mississippi, pelicans were monitored to determine their daily activity budgets while using different habitats such as catfish ponds, crawfish ponds, rivers, lakes, and bayous. Pelicans foraging at catfish ponds spent about $4 \%$ of their day foraging and $96 \%$ loafing, whereas pelicans foraging in other habitats spent about $28 \%$ of their day foraging and $72 \%$ loafing. This difference may be due to pelicans being more efficient in obtaining their food requirements from catfish ponds (King and Werner 2001).

\subsubsection{Distribution and numbers}

Most pelican biologists believe that American white pelicans are separated by the continental divide into two geographically distinct populations (King 1995). In 1981, the entire North American population of American white pelicans was estimated at 109,000, with about 77,000 birds wintering and summering east of the Rocky Mountains (Johnsgard 1993). Although published data on the status of the pelican population since 1981 are lacking, the current eastern population is estimated at more than 120,000 birds (Tommy King, USDA-National Wildlife Research Center, Mississippi State, Mississippi, unpublished data). In the United States, the largest known breeding colonies of American white pelicans east of the Rocky Mountains are at Chase Lake National Wildlife Refuge, North Dakota and Marsh Lake, Minnesota.

The eastern population of American white pelicans migrates primarily through the Great Plains and along the Mississippi River and winters in the lower Mississippi River Valley and along the Gulf Coast (Evans and Knopf 1993; Johnsgard 1993; King and Grewe 2001). Aerial 

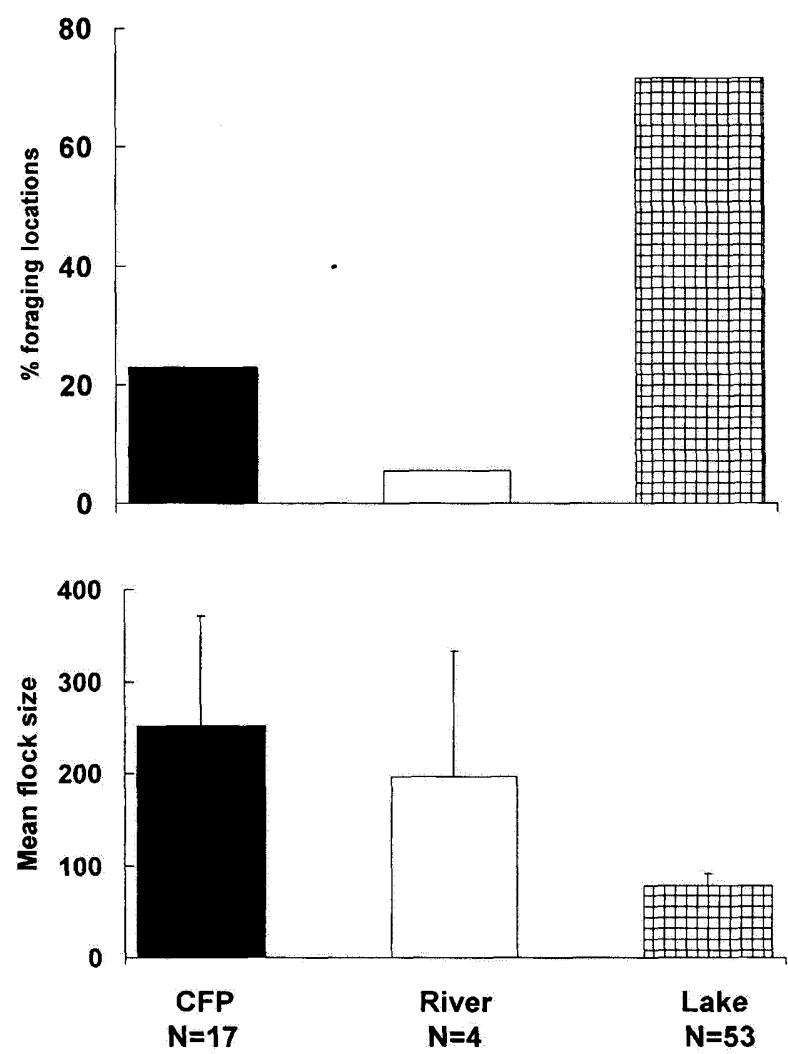

FIGURE 16.7. Distribution (\%) among primary foraging locations and mean ( \pm standard error of the mean) flock size of American white pelicans observed on catfish ponds (CFP), rivers, and lakes during aerial surveys in the catfish production region of northwest Mississippi, 1993 through 1997 (King and Werner 2001).

censuses conducted in northwest Mississippi showed that the numbers of pelicans peaked at fewer than 7,000 in February and March, corresponding with the onset spring migration (King and Grewe 2001; King and Michot 2002). However, there was no significant increase in wintering pelican numbers recorded between 1994 and 1997 (King and Werner 2001). Prior to winter and spring 1995, pelicans in Arkansas, south Louisiana and Mississippi usually foraged in large flocks. It was common to see more than 300 pelicans flying to catfish ponds, foraging, and leaving in one flock. Now however, it is not uncommon to see pelicans foraging in small flocks ( 1 to 50 birds) and recent data suggest a mean flock size on catfish ponds to be 251 pelicans (King and Werner 2001; Fig. 16.7).

\subsubsection{Diet and depredation problems}

Although depredation problems associated with pelicans may be significant where they occur, problems appear more isolated than those caused by cormorants. As many as 2,000 pelicans have 
been observed foraging in one 6-ha (15-acre) pond in Mississippi (King and Werner 2001), but in 1996 only $8 \%$ of catfish producers reported depredation problems caused by pelicans (Wywialowski 1999). King and Werner (2001) report that pelicans are most often observed feeding in lakes but occur in larger flocks on catfish ponds than lakes (Fig. 16.7). Although little is known about pelican energetic demands, Lingle (1977) found that breeding adult pelicans at Chase Lake National Wildlife Refuge, North Dakota consumed about $0.6 \mathrm{~kg}$ ( 1.3 pounds) of food per day. In contrast, Cooper (1980) reported that the larger $(8.9 \mathrm{~kg} ; 19.6$ pounds) great white pelican in Africa consumed $14.1 \%$ of their body mass in fish each day. Assuming the same percentage, American white pelicans would require $0.9 \mathrm{~kg}$ ( 3.1 pounds) of fish/bird per day. Relative to the food requirement of a cormorant $(0.5 \mathrm{~kg} / \mathrm{bird}$ per day; 1.1 pound/bird per day $)$, the latter may be more realistic for a bird more than twice the size of a cormorant.

In preliminary studies (King 1995), catfish up to $34 \mathrm{~cm}$ (ca. 13 inches) long were found in stomachs of pelicans, and several catfish larger than $53 \mathrm{~cm}$ (ca. 21 inches) long were found stuck in throats of pelicans collected from northwest Mississippi. In the latter cases, pelicans apparently tried to swallow the larger catfish tail first and the pectoral spines of the catfish pierced the pelican's throat, preventing swallowing (King 1995). More recently, 28 pelicans collected while loafing near catfish ponds in northwest Mississippi had a diet consisting of $99.6 \%$ catfish by weight (Tommy King, USDA-National Wildlife Research Center, Mississippi State, Mississippi, unpublished data). Of the 162 mostly intact catfish measured from these stomach contents, the mean size of fish consumed was $26 \mathrm{~cm}$ (10.2 inches), but catfish up to $63 \mathrm{~cm}$ (24.8 inches) in length were found in these birds. The calculated biomass of fish consumed corresponded to slightly in excess of $3 \mathrm{~kg}$ ( 6.6 pounds) of catfish being consumed by a single pelican, but the mean biomass of catfish consumed by 27 pelicans, presumably from a single feeding, was 528 g (1.2 pounds) (Tommy King, USDA-National Wildlife Research Center, Mississippi State, Mississippi, unpublished data).

In addition to pelicans consuming catfish, they are involved in the transmission of devastating parasitic infections to catfish. Pelicans have recently been identified as one of the hosts in the life cycle of commercial catfish parasites, especially the digenetic trematode Bolbophorus damnificus (Overstreet et al. 2002). This trematode has been responsible for substantial economic losses to several aquaculture producers in Louisiana, northwest Mississippi, and southeast Arkansas (see Chapters 13 and 14).

\subsubsection{Economics of depredation}

Although data to clearly define the economics of pelican depredations are lacking, the economic impact of pelicans to aquaculture on a regional scale is probably less than that of cormorants because their seasonal abundance is typically lower. For instance, in northwest Mississippi, peak populations of less than 7,000 pelicans have been a small fraction of the 67,000 cormorants observed (Glahn et al. 2000b). However, at a pond scale, pelican depredations can be economically more important than that of cormorants because of the amount and size of catfish consumed. If pelicans foraging in a catfish pond consumed exclusively catfish averaging $26 \mathrm{~cm}$ (10.2 inches), then each bird would require 11 of these catfish to meet its energetic requirement of $0.9 \mathrm{~kg} /$ day (ca. 2 pounds/day). This consumption rate would translate into 2,750 catfish consumed/day by an average flock of 250 pelicans. If these fish reached harvestable size of 0.68 $\mathrm{kg}(1.5$ pounds) and were valued at $\$ 1.54 / \mathrm{kg}(\$ 0.70 /$ pound $)$, catfish farmers could potentially lose 
approximately $\$ 2,900$ from a single day of pelican foraging. Actual depredation losses would depend on actual pelican abundance at ponds, the size and therefore the number of catfish that could be consumed, and the duration of pelican foraging at catfish ponds. For instance, recent fragmentation of some pelican foraging flocks can lessen the impact on a pond or farm if the number of days pelicans forage at ponds can be minimized.

Although the economic impact of pelican foraging can be significant, the potential for pelicans to transmit trematode infections.to catfish ponds can be more devastating. Entire populations of catfish have died from trematode infections, and managing the disease involves frequent monitoring of fish populations and chemical treatment of ponds to kill the other intermediate host of the parasite-the rams-horn snail (see Section 15.11).

\subsubsection{Prevention and control of depredations}

Prior to the winter of 1992-1993, pelican depredations at catfish facilities in the delta regions of Arkansas and Mississippi were limited to infrequent visits and the birds were easily dispersed from the area. In recent years however, pelicans have become more persistent in their foraging efforts and more difficult to disperse from catfish farms (King 1995). Damage abatement recommendations by King (1995) have consisted of harassment measures similar to those used for cormorants (i.e., harassment patrols, pyrotechnics, electronic noise devices, human effigies, and propane cannons), issuance of depredation permits, and draining water from flooded agricultural fields where pelicans loaf. Because pelicans often forage at night, 24-hour harassment patrols may become necessary in areas experiencing problems. In south Louisiana, nocturnally foraging pelicans have been easily frightened from catfish ponds using bright spotlights (Albert Gaudé III, Clearwater Cajun Fisheries, St. Martinville, Louisiana, personal communication). The more recent fragmentation of some pelican flocks makes harassment and dispersal from ponds much more difficult. Thus, the most effective technique seems to be harassing the birds at their loafing sites near catfish farms.

\subsubsection{Costs and benefits of control}

Considering the potential for extensive losses caused by pelican foraging at catfish ponds, deterring pelicans from foraging on ponds is clearly warranted. If allowed to land on catfish ponds, pelicans will immediately begin to forage. Therefore, every effort should be made to prevent flocks of pelicans from landing. Prompt and persistent action is needed to preclude large losses from occurring. Lack of vigilance by harassment patrols during a mid-day break or at night may allow substantial damage to take place despite control efforts. Although the costs of pelican control rarely have been reported, during the winter of 1994-95 one catfish farmer in south Louisiana estimated his costs for pyrotechnics, ammunition, and labor for pelican harassment to be $\$ 129,345$, with an additional $\$ 12,710$ spent for extra road and vehicle maintenance (Albert Gaudé III, Clearwater Cajun Fisheries, St. Martinville, Louisiana, personal communication). In spite of these expenditures, this farmer estimated losing $\$ 31,227$ in fish due to depredations. However, without persistent harassment efforts these losses probably would have been higher. 


\section{REFERENCES}

Aderman, A.R. and E.P. Hill. 1995. Locations and numbers of double-crested cormorants using winter roosts in the delta region of Mississippi. Colonial Waterbirds 18 (Special Publication 1):143-151.

Anderson, J.G.T. 1987. Foraging behavior of American white pelicans (Pelecanus erythrorhynchos) in western Nevada. Ph.D. dissertation, University of Rhode Island, Providence, Rhode Island, USA.

Avery, M.L., D.S. Eiselman, M.K. Young, J.S. Humphrey, and D.G. Decker. 1999. Wading bird predation at tropical aquaculture facilities in central Florida. North American Journal of Aquaculture 61:64-69.

Barlow, C.G. and K. Bock. 1984. Predation of fish in farm dams by cormorants, Phalacrocorax spp. Australian Wildlife Research 11:559-566.

Bennett, D.C. 1993. Growth and energy requirements of captive great blue herons (Ardea herodias). Master's thesis. University of British Columbia, Vancouver, British Columbia, Canada.

CEAH (Centers for Epidemiology and Animal Health). 1997a. Catfish 97: Part I. Reference of 1996 U.S. catfish health and production practices. United States Department of Agriculture, Animal and Plant Health Inspection Service, Veterinary Services, Fort Collins, Colorado, USA.

CEAH (Centers for Epidemiology and Animal Health). 1997b. Catfish 1997. Part II. Reference of 1996 U.S. catfish. management practices. United States Department of Agriculture, Animal and Plant Health Inspection Service, Veterinary Services, Fort Collins, Colorado, USA.

Cooper, J. 1980. Energetic requirements for maintenance of a captive juvenile Great White Pelican Pelecanus onocrotalus. Cormorant 8:17-18.

Cottam C. and F.M. Uhler 1945. Birds in relation to fishes. Leaflet 272. United States Fish and Wildlife Service, Washington DC, USA.

Davis. J.T. 1990. Field trials of string and streamer controls on bird depredations at research ponds. Unpublished report. Texas A\&M Cooperative Extension Service, College Station, Texas, USA.

Dolbeer, R.A. 1990. Double-crested cormorant population status in North America, 1970-1989. Bird Section Research Report No. 451, Denver Wildlife Research Center, Denver, Colorado, USA.

Dolbeer, R.A. 1991. Migration patterns of double-crested cormorants east of the Rocky Mountains. Journal of Field Ornithology 62:83-93.

Draulins, D. 1988. Effects of fish-eating birds on freshwater fish stocks: An evaluation. Biological Conservation 44:251-263.

Engle, C.R. and P.J. Kouka. 1996. Effects of inflation on the cost of producing catfish. Report submitted to The Catfish Bargaining Association. University of Arkansas at Pine Bluff, Pine Bluff, Arkansas, USA.

Erwin, R.M. 1995. The ecology of cormorants: Some research needs and recommendations. Colonial Waterbirds 18 (Special Publication 1):240-246.

Evans, R.M. and F.L. Knopf. 1993. American White Pelican. In A. Poole and F. Gill (editors): The Birds of North America, Number 57. The Academy of Natural Sciences, Philadelphia and The American Ornithologists' Union, Washington DC, USA.

Garrard, A.B., J.M. Burney, M.E. Keenum, and J.E. Waldrop. 1990. Effect of pond size on cost of producing farmraised catfish in the delta area of Mississippi. Bulletin 172, Mississippi Agricultural and Forestry Experiment Station, Mississippi State, Mississippi, USA.

Glahn, J.F. 2000. Comparison of pyrotechnics versus shooting for dispersing double-crested cormorants from their night roosts. Pages 44-48 in Proceedings of the Nineteenth Vertebrate Pest Conference, 6-9 March 2000, San Diego, California, USA,

Glahn, J.F. and K.E. Brugger. 1995. The impact of double-crested cormorants on the Mississippi delta catfish industry: a bioenergetics model. Colonial Waterbirds 18 (Special Publication. 1):168-175.

Glahn, J.F. and B.S. Dorr. 2002. Captive double-crested cormorant Phalacrocorax auritus predation on channel catfish Ictalurus punctatus fingerlings and its influence on single-batch cropping production. Journal of the World Aquaculture Society 33:85-93.

Glahn, J.F. and A. R. Stickley, Jr. 1995. Wintering double-crested cormorants in the delta region of Mississippi: Population levels and their impact on the catfish industry. Colonial Waterbirds 18 (Special Publication 1): $137-142$.

Glahn, J.F., P.J. Dixon, G.A. Littauer, and R.B. McCoy. 1995. Food habits of double-crested cormorants wintering in the delta region of Mississippi. Colonial Waterbirds 18 (Special Publication 1):158-167. 
Glahn, J.F., B.S. Dorr, J.B. Harrel, and L. Khoo. 2002b. Foraging ecology and depredation management of great blue herons at Mississippi catfish farms. Journal of Wildlife Management 66:194-201.

Glahn, J.F., B. Dorr, and M.E. Tobin. 2000c. Captive great blue heron predation on farmed channel catfish fingerlings. North American Journal of Aquaculture 62:149-156.

Glahn, J.F., G. Ellis, P. Fiornelli, and B.S. Dorr. 2001. Evaluation of moderate- and low-powered lasers for dispersing cormorants from their night roosts. Pages 34-48 in Proceedings of Ninth Eastern Wildlife Damage Management Conference, 5-8 October 2000, State College, Pennsylvania, USA.

Glahn, J.F., A. May, K. Bruce, and D. Reinhold. 1996. Censusing double-crested cormorants (Phalacrocorax auritus) at their winter roosts in the Delta Region of Mississippi. Colonial Waterbirds 19:73-81.

Glahn, J.F., E.S. Rasmussen, T. Tomsa, and K. Preusser. 1999a. Distribution and relative impact of avian predators at aquaculture facilities in the northeastern United States. North American Journal of Aquaculture 61:340-348.

Glahn, J.F., D.S. Reinhold, and C.A. Sloan. 2000b. Recent population trends of double-crested cormorants wintering in the delta region of Mississippi: Responses to roost dispersal and removal under a recent depredation order. Waterbirds 23(1):38-44.

Glahn, J.F., D.S. Reinhold, and P. Smith. 1999b. Wading bird depredations on channel catfish Ictalurus punctatus in the delta region of Mississippi. Journal of the World Aquaculture Society 30:107-114.

Glahn, J.F., M.E. Tobin, and B.F. Blackwell. 2000a. A science-based initiative to manage double-crested cormorant damage to southern aquaculture. APHIS 11-55-010. U.S. Department of Agriculture, Animal and Plant Health Inspection Service, Wildlife Services National Wildlife Research Center, Fort Collins, Colorado, USA.

Glahn, J.F., S.J. Werner, T. Hanson, and C.R. Engle. 2002a. Cormorant depredation losses and their prevention at catfish farms: Economic considerations. Pages 138-146 in Human Conflicts with Wildlife: Economic Considerations Conference, 1-3 August 2000, Fort Collins, Colorado, USA.

Gottfried, R.W. 1998. Test of submerged structures as a deterrent to double-crested cormorant predation of channel catfish at catfish farms. Master's thesis. Louisiana State University. Baton Rouge, Louisiana, USA.

Hart, S.D. 1989. American white pelican (Pelecanus erythrorhynchos) populations, kleptoparasitism, and other foraging behaviors at American Falls Reservoir, southeast Idaho. Master's thesis. Idaho State University, Boise, Idaho, USA.

Hatch, J.J. 1995. Changing populations of double-crested cormorants. Colonial Waterbirds 18 (Special Publication 1):8-24.

Hatch, J.J. and D.V. Weseloh. 1999. Double-crested cormorant (Phalacrocorax auritus). In A. Poole and F. Gill (editors): The Birds of North America, Number 441. The Academy of Natural Sciences, Philadelphia and The American Ornithologists' Union, Washington DC, USA

Hess, K. 1994. Effectiveness of shooting double-crested cormorants on catfish ponds and harassment of roosts to protect farm-raised catfish. Master's thesis. Mississippi State University, Mississippi, USA.

Hodges, M.F. 1989. Depredation of channel catfish by birds on Mississippi catfish farms. Master's thesis, Mississippi State University, Mississippi, USA.

Hoy, M., J. Jones, and A. Bivings. 1989. Economic impact and control of wading birds at Arkansas minnow ponds. Pages 109-1 12 in S. R. Craven, editor. Proceedings of the Fourth Eastern Wildlife Damage Control Conference, 25-28 September 1989, Madison, Wisconsin, USA.

Jackson, J.A. and B.J.S. Jackson. 1995. The double-crested cormorant in the south-central United States: habitat and population changes of a feathered pariah. Colonial Waterbirds 18 (Special Publication 1):118-130.

Johnsgard, P.A. 1993. Cormorants, Darters, and Pelicans of the World. Smithsonian Institution Press, Washington DC, USA.

Johnson, R.F., Jr. 1976. Mortality factors affecting a white pelican population, Chase Lake National Wildlife Refuge, North Dakota. Master's thesis. Michigan Technological University, Houghton, Michigan, USA.

Keller, T.M. 1999. Wiring and enclosure systems as tools to reduce cormorant depredations at fish farms. Pages 239-249 in D.P. Cowand and C.J. Feare (editors): Advances in Pest Management. Filander Verlag, Fürth, Germany.

King, D.T. 1995. American White Pelicans: The latest avian problem for catfish producers. Pages 31-35 in Proceedings Seventh Eastern Wildlife Damage Management Conference, 5-8 November 1995, Jackson, Mississippi, USA.

King, D.T. 1996. Movement of double-crested cormorants among winter roosts in the delta region of Mississippi. Journal of Field Ornithology 67:205-211.

King, D.T. and A.H. Grewe, Jr. 2001. Movements and mortality of American white pelicans banded at Marsh Lake, Minnesota. North American Bird Bander 26:57-60. 
King, D.T. and T.C. Michot. 2002. Distribution, abundance, and habitat use of American white pelicans in the delta region of Mississippi and along the western Gulf of Mexico coast. Waterbirds 25:410-416.

King, D.T. and S. J. Werner. 2001. Daily activity budgets and population size of American white pelicans wintering in south Louisiana and the delta region of Mississippi. Waterbirds 24:250-254.

King, D.T., J.F. Glahn, and K.J. Andrews. 1995. Daily activity budgets and movements of winter roosting doublecrested cormorants determined by biotelemetry in the delta region of Mississippi. Colonial Waterbirds 18 (Special Publication 1):152-157.

Kuslan, J.A. 1976. Wading bird predation in a seasonally fluctuating pond. Auk 93:464-476,

Lewis, H.F. 1929. The Natural History of the Double-crested Cormorant (Phalacrocorax auritus auritus (Lesson)). Ru-Mi-Lou Books, Ottawa, Canada.

Lingle, G.R. 1977. Food habits and aging criteria of the white pelican at Chase Lake National Wildlife Refuge, North Dakota. Master's thesis. Michigan Technological University, Houghton, Michigan, USA.

Littauer, G.A., J.F. Glahn, D.S. Reinhold, and M.W. Brunson. 1997. Control of bird predation at aquaculture facilities: Strategies and cost estimates. Southern Regional Aquaculture Center Publication No. 402, Southern Regional Aquaculture Center, Stoneville, Mississippi, USA.

Mastrangelo, P., C. Sloan, and K. Bruce. 1995. Incorporating depredation permits into integrated damage management plans for aquaculture facilities. Pages 36-39 in J. B. Armstrong (editor): Proceedings of Seventh Eastern Wildlife Damage Management Conference, 5-8 November 1995, Jackson, Mississippi, USA,

May, J.A. and M.J. Bodenchuk. 1992. "Wire" grid excludes cormorants from commercial catfish ponds. Probe 125:4.

McMahon, B.F. and R.M. Evans. 1992. Foraging strategies of American white pelicans. Behaviour 120:69-89.

Meister, A.L. and F.J. Gramlich. 1967. Cormorant predation on tagged Atlantic salmon smolts. Maine Atlantic SeaRun Commission. Unpublished report. University of Maine, Orono, Maine, USA.

Moerbeek, D.J., W.H. Van Dobben, E.R. Osieck, G.C. Boere, and C.M. Bungenberg De Jong. 1987. Cormorant damage prevention at a fish farm in the Netherlands. Biological Conservation 39:23-38.

Mott, D.F. and F.L. Boyd. 1995. A review of techniques for preventing cormorant depredations at aquaculture facilities in the Southeastern United States. Colonial Waterbirds 18 (Special Publication) 1:176-180.

Mott, D.F. and M.W. Brunson. 1995. A historical perspective of catfish production in the southeast in relation to avian predation. Pages $23-30$ in J.B. Armstrong (editor): Proceedings of Seventh Eastern Wildlife Damage Management Conference, 5-8 November 1995, Jackson, Mississippi, USA.

Mott, D.F. and R.D. Flynt. 1995. Evaluation of an electric fence system for excluding wading birds from catfish farms. Progressive Fish-Culturist 57:88-90.

Mott, D.F., K.J. Andrews, and G.A. Littauer. 1991. An evaluation of roost dispersal for reducing cormorant activity on catfish ponds. Pages 205-211 in P. D. Curtis, M. J. Fargione, and J. E. Caslick (editors): Proceedings Fifth Eastern Wildlife Damage Control Conference, 6-9 October 1991, Ithaca, New York, USA.

Mott, D.F., R.D. Flynt, and J.O. King. 1993. An evaluation of floating ropes for reducing cormorant damage at catfish ponds. Pages 93-97 in M.M. King (editor): Proceedings Sixth Eastern Wildlife Damage Control Conference, 3-6 October 1993, Asheville, North Carolina, USA.

Mott, D.F., J.F. Glahn, P.L. Smith, D.S. Reinhold, K.J. Bruce, and C.A. Sloan. 1998. An evaluation of dispersing double-crested cormorants from winter roosts for reducing predation on catfish in Mississippi. Wildlife Society Bulletin 26:584-591.

Overstreet, R.M., S.S. Curran, L.M. Pote, D.T. King, C.K. Blend, and W.D. Grater. 2002. Bolbophorus damnificus n.sp. (Digenea Bolbophoridae) from the channel catfish Ictalurus punctatus and American white pelican Pelecanus erythrorhynchos in the USA based on life-cycle and molecular data. Systematic Parasitology 52:81-96.

Parkhurst, J.A., R.P. Brooks, and D.E. Arnold. 1992. Assessment of predation at trout hatcheries in Central Pennsylvania. Wildlife Society Bulletin 20:411-419.

Pitt, W.C. and M.R.Conover. 1996. Predation at intermountain west fish hatcheries. Journal of Wildlife Management 60:616-624.

Reinhold, D.S. and C.A. Sloan. 1999. Strategies to reduce double-crested cormorant depredation at aquaculture facilities in Mississippi. Pages 99-105 in M. E. Tobin (Technical Coordinator): Symposium on double-crested cormorants: Population status and management issues in the Midwest. Animal and Plant Health Inspection Service Technical Bulletin 1879, United States Department of Agriculture, Washington DC, USA.

Reinhold, D.S., A.J. Mueller, and G. Ellis. 1998. Observations of nesting double-crested cormorants in the delta region of Mississippi. Colonial Waterbirds 21:466-467. 
Ross, P.G. 1994. Foraging ecology of wading birds at commercial aquaculture facilities in Alabama. Master's thesis. Auburn University, Alabama, USA.

Schramm, H.L., Jr., M.W. Collopy, and E.A. Okrah. 1987. Potential problems of bird predation for fish culture in Florida. Progressive Fish-Culturist 49:44-49.

Schramm, H.L., Jr., B. French, and M. Ednoff. 1984. Depredation of channel catfish by Florida double-crested cormorants. Progressive Fish-Culturist 46:41-43.

Stickley, A.R. Jr. 1990. Avian predators on southern aquaculture. Southern Regional Aquaculture Center Publication No. 400, Southern Regional Aquaculture Center, Stoneville, Mississippi, USA.

Stickley, A.R., Jr. and K.J. Andrews. 1989. Survey of Mississippi catfish farmers on means, effort, and costs to repel fish-eating birds from ponds. Pages $105-108$ in Proceedings of the Fourth Eastern Wildlife Damage Control Conference, 25-28 September 1989, Madison, Wisconsin, USA.

Stickley, A.R., Jr., J.F. Glahn, J.O King, and D.T. King. 1995. Impact of great blue heron depredations on channel catfish farms. Journal of the World Aquaculture Society 26:194-199.

Stickley, A.R., Jr., G.L. Warrick, and J.F. Glahn. 1992. Impact of double-crested cormorant populations on channel catfish farms. Journal of the World Aquaculture Society 23:192-198.

Taylor, P.W. 1992. Fish-eating birds as potential vectors of Edwardsiella ictaluri. Journal of Aquatic Animal Health 4:240-243.

Tucker, C.S. and E.H. Robinson. 1990. Channel Catfish Farming Handbook. Van Nostrand Reinhold, New York, New York, USA.

Tucker, C.S., J.A. Steeby, J.E. Waldrop, and A.B. Garrard. 1992. Effects of cropping system and stocking density on production of channel catfish in ponds. Mississippi Agricultural and Forestry Experiment Station Bulletin 988, Mississippi State University, Mississippi, USA.

Tyson, L.A., J.L. Belant, F.J. Cuthbert, and D.V.C. Weseloh. 1999. Nesting populations of double-crested cormorants in the United States and Canada. Pages 17-25 in M. E. Tobin (Technical Coordinator): Symposium on double-crested cormorants: Population status and management issues in the Midwest. Animal and Plant Health Inspection Service Technical Bulletin 1879, United States Department of Agriculture, Washington DC, USA.

USDI-FWS (United States Department of the Interior-Fish and Wildlife Service). 1998. Migratory bird permits; establishment of a depredation order for the double-crested cormorant (Final rule). USDI/Fish and Wildlife Service, 50 CFR Part 21, RIN 1018-AE11.

Waterstrat, P.R., B. Dorr, J.F. Glahn, and M.E. Tobin, 1999. Recovery and viability of Edwardsiella ictaluri from great blue herons Ardea herodias fed $E$. ictaluri-infected channel catfish Ictalurus punctatus fingerlings. Journal of the World Aquaculture Society 30:115-122.

Werner, S.J. 2000. Cormorant research and impacts to southern aquaculture. Pages 81-83 in Proceedings of the Nineteenth Vertebrate Pest Conference, 6-9 March 2000, San Diego, California, USA,

Willard, D.E. 1977. The feeding ecology and behavior of five species of herons in southeastern New Jersey. The Condor 79:462-470.

Wywialowski, A.P. 1999. Wildlife-caused losses for producers of channel catfish (Ictalurus punctatus) in 1996. Journal of The World Aquaculture Society 30:461-472. 